\title{
Fibrillar $\beta$-Amyloid Induces Microglial Phagocytosis, Expression of Inducible Nitric Oxide Synthase, and Loss of a Select Population of Neurons in the Rat CNS In Vivo
}

\author{
Derik T. Weldon, ${ }^{1}$ Scott D. Rogers, ${ }^{2}$ Joseph R. Ghilardi, ${ }^{2}$ Matthew P. Finke, ${ }^{2}$ James P. Cleary, ${ }^{3,5}$ \\ Eugene O'Hare, ${ }^{4,5}$ William P. Esler, ${ }^{6}$ John E. Maggio, ${ }^{6}$ and Patrick W. Mantyh ${ }^{2}$ \\ ${ }^{1}$ School of Medicine, Departments of ${ }^{2}$ Preventive Sciences, ${ }^{3}$ Psychology, and ${ }^{4}$ Pharmacology, University of Minnesota, \\ Minneapolis, Minnesota 55455, 5Geriatric Research Education and Clinical Center, Veterans Affairs Medical Center, \\ Minneapolis, Minnesota 55417, and ${ }^{6}$ Department of Pharmacology and Cell Biophysics, University of Cincinnati, \\ Cincinnati, Ohio 45267
}

To determine the stability of $\beta$-amyloid peptide $(\mathrm{A} \beta)$ and the glial and neuronal changes induced by $A \beta$ in the CNS in vivo, we made single injections of fibrillar $A \beta(f A \beta)$, soluble $A \beta(s A \beta)$, or vehicle into the rat striatum. Injected $\mathrm{f} A \beta$ is stable in vivo for at least $30 \mathrm{~d}$ after injection, whereas $\mathrm{s} A \beta$ is primarily cleared within 1 d. After injection of $\mathrm{f} A \beta$, microglia phagocytize $\mathrm{f} A \beta$ aggregates, whereas nearby astrocytes form a virtual wall between $\mathrm{fA} \beta$-containing microglia and the surrounding neuropil. Similar glial changes are not observed after $\mathrm{sA} \beta$ injection. Microglia and astrocytes near the injected $\mathrm{f} A \beta$ show a significant increase in inducible nitric oxide synthase (iNOS) expression compared with that seen with $\mathrm{sA} \beta$ or vehicle injection. Injection of $\mathrm{fA} \beta$ but

Alzheimer's disease (AD) is a neurodegenerative disease characterized by progressive memory loss and dementia. The pathological hallmarks of $\mathrm{AD}$ are extracellular plaques containing $\beta$-amyloid (A $\beta$ ), dystrophic neurites, activated microglia, reactive astrocytes, and neuronal loss (Selkoe, 1991). Several lines of evidence suggest that $A \beta$ is directly involved in the neuropathology observed in AD. $\mathrm{A} \beta$ deposition is an invariant feature of $\mathrm{AD}$, and there is a strong correlation between amyloid burden at death and the degree of dementia in life (Selkoe, 1994; Cummings and Cotman, 1995). Most importantly, several genetically heritable forms of $\mathrm{AD}$ are tightly linked to mutations of the amyloid precursor protein gene on chromosome 21 (Goate et al., 1991), which cause an increase in $\mathrm{A} \beta$ production (Citron et al., 1992). Heritable forms of AD linked to mutations on chromosomes 14 and 1 also seem to alter A $\beta$ processing (Scheuner et al., 1996; Selkoe, 1997).

$\mathrm{A} \beta$ is a 39-43-amino-acid hydrophobic peptide encoded by the gene for the much larger amyloid precursor protein (Glenner and Wong, 1984; Kang et al., 1987). A $\beta$ is constitutively produced in cells, and soluble $\mathrm{A} \beta(\mathrm{sA} \beta)$ is present at similar concentrations

Received Aug. 18, 1997; revised Dec. 16, 1997; accepted Dec. 31, 1997.

This work was supported by National Institutes of Health Grants AG11852, NS23970, and AG12853, by the Veterans Administration Merit Review, and by Alzheimer's Association Grant PRG94-194. We thank Dr. Dennis Selkoe for the contribution of anti-A $\beta$ R1282 and Evelyn Stimson for preparation of the ${ }^{125} \mathrm{I}-\mathrm{A} \beta$ tracer.

Correspondence should be addressed to Dr. Patrick W. Mantyh, Department of Preventive Sciences, University of Minnesota, 515 Delaware Street, Minneapolis, MN 55455.

Copyright (C) 1998 Society for Neuroscience $\quad 0270-6474 / 98 / 182161-13 \$ 05.00 / 0$ not $s A \beta$ or vehicle induces a significant loss of parvalbuminand neuronal nitric oxide synthase-immunoreactive neurons, whereas the number of calbindin-immunoreactive neurons remains unchanged. These data demonstrate that $\mathrm{f} A \beta$ is remarkably stable in the CNS in vivo and suggest that $\mathrm{fA} \beta$ neurotoxicity is mediated in large part by factors released from activated microglia and astrocytes, as opposed to direct interaction between $A \beta$ fibrils and neurons.

Key words: Alzheimer's disease; glia; microglia; astrocyte; neurotoxicity; nitric oxide synthase; inducible nitric oxide synthase

$\left(10^{-9} \mathrm{M}\right)$ in normal and $\mathrm{AD} C \mathrm{CSF}$, indicating that $\mathrm{A} \beta$ is a natural rather than a pathogenic product (Haass et al., 1992; Seubert et al., 1992; Shoji et al., 1992; Busciglio et al., 1993; van Gool et al., 1995). Several studies have shown that $\mathrm{sA} \beta$ will spontaneously form insoluble aggregates at high concentrations $\left(10^{-3}\right.$ to $10^{-5}$ M) and that the presence of other factors, such as metals, proteoglycans, or apoliopoprotein E4, can influence $\mathrm{A} \beta$ aggregation (Fraser et al., 1992; Mantyh et al., 1993; Bush et al., 1994; Ma et al., 1994; Sanan et al., 1994; Wisniewski et al., 1994; Evans et al., 1995; Esler et al., 1996).

Conversion of $\mathrm{sA} \beta$ to insoluble, fibrillar $\mathrm{A} \beta$ (fA $\beta$ ), an $\mathrm{A} \beta$ conformation similar to that found in the $\mathrm{AD}$ brain, has been reported to increase greatly $\mathrm{A} \beta$ toxicity in neuronal cultures (Pike et al., 1991a,b, 1993, 1995; Mattson et al., 1992). However, other studies have reported that $\mathrm{sA} \beta$ at concentrations near that found in human CNS $\left(10^{-9} \mathrm{M}\right)$ has marked neurotoxic and/or neuroprotective effects on neurons in vitro (Koh et al., 1990; Yankner et al., 1990; Harrigan et al., 1995; Kelly et al., 1996). Although much of the above data suggest that $\mathrm{A} \beta$ is neurotoxic in vitro, substantial uncertainty remains as to the form of $\mathrm{A} \beta$ that is neurotoxic in vivo, the long-term stability of $\mathrm{A} \beta$, and the mechanism(s) via which $\mathrm{A} \beta$ may induce neurotoxicity in vivo.

In the present study, we use microglia, astrocyte, and neuronal markers to study the glial and neuronal changes induced by soluble and fibrillar forms of $\mathrm{A} \beta$ in the CNS in vivo. The use of microglia and astrocyte markers allows us to address the question of direct versus indirect toxicity of $\mathrm{A} \beta$ and to determine whether microglia and astrocytes are differentially involved in the CNS 
response to $\mathrm{A} \beta$. We chose the striatum as the CNS area in which to examine the effects of $\mathrm{A} \beta$, because this forebrain area is affected in AD (Selden et al., 1994), is a relatively homogeneous brain area that allows quantification of $\mathrm{A} \beta$-induced cellular changes, and has well defined neuronal subpopulations that are readily quantifiable using immunohistochemical methods (Kawaguchi et al., 1995). In the present study, we have also used confocal microscopy, because this imaging technique allows us to visualize simultaneously several fluorescent markers while providing unequivocal single-cell and intracellular resolution of the changes that $\mathrm{A} \beta$ induces in the $\mathrm{CNS}$.

\section{MATERIALS AND METHODS}

Preparation and characterization of fibrillar and soluble $A \beta$. A $\beta 1-40$, synthesized by fluorenylmethoxycarbonyl chemistry and purified to near homogeneity (>98\%), was obtained (Quality Control Biochemicals, Hopkinton, MA) and stored lyophilized at $-20^{\circ} \mathrm{C}$. Peptides used to produce $\mathrm{fA} \beta$ and $\mathrm{sA} \beta$ were characterized by reverse phase (RP)-HPLC, laser desorption mass spectroscopy (LD-MS), amino acid analysis (Benson et al., 1981), and size exclusion fast-protein liquid chromatography (SE-FPLC) (Soreghan et al., 1994).

Fibrillar $\mathrm{A} \beta$ was prepared from solutions of $10^{-4} \mathrm{M} \mathrm{A} \beta$ in filtered PBS (10.0 mM NaH $\mathrm{PO}_{4} / \mathrm{Na}_{2} \mathrm{HPO}_{4}$ and $100.0 \mathrm{~mm} \mathrm{NaCl}, \mathrm{pH}$ 7.5). Peptide solutions were initially clear, with no evidence of flocculation or incomplete dissolution; visible precipitate appeared only after extended agitation. The fresh $\mathrm{A} \beta$ solution was allowed to incubate under vigorous agitation (Teflon-coated stir bar at $800 \mathrm{rpm}$ ) (Jarrett and Lansbury, 1992; Jarrett et al., 1993, 1994; Evans et al., 1995) at $23^{\circ} \mathrm{C}$ for $26-36$ hr. After this incubation, the $\mathrm{A} \beta$ solution was distinctly turbid, and $>80 \%$ of the peptide could be sedimented by centrifugation $(15,000 \times g ; 10 \mathrm{~min})$. The fA $\beta$ solution was aliquoted (100 $\mu \mathrm{l}$ per vial), frozen on dry ice, and stored at $-20^{\circ} \mathrm{C}$ until use.

To better characterize the $\mathrm{fA} \beta$ assembly reaction, we performed time course experiments in triplicate with mixtures of ${ }^{125} \mathrm{I}-\mathrm{A} \beta$ and unlabeled $\mathrm{A} \beta$ in microcentrifuge tubes (Evans et al., 1995) under conditions similar to those described above. At each time point, a $15 \mu \mathrm{l}$ aliquot was taken from each tube and centrifuged $(15,000 \times g ; 10 \mathrm{~min})$, and the amount of ${ }^{125} \mathrm{I}-\mathrm{A} \beta$ in each of two $3 \mu \mathrm{l}$ aliquots of the resulting supernatants was quantified using a gamma counter. Fibrillar $\mathrm{A} \beta$ assembly followed a distinctly nonlinear time course with a lag time, indicative of a nucleation-dependent aggregation process (Jarrett and Lansbury, 1993). Fibrillar $\mathrm{A} \beta$ from the preparative procedure described above was characterized by thioflavin $\mathrm{S}$, Congo red, and anti-A $\beta$ immunohistochemical staining and then was examined for size distribution using light-field or fluorescence microscopy and image analysis. Individual fA $\beta$ aggregates had a median diameter of $12.3 \mu \mathrm{m}$, which compares favorably with the diameter of plaque cores $(5-30 \mu \mathrm{m})$ purified from human $\mathrm{AD}$ brain (Selkoe and Abraham, 1986). Like amyloid plaques found in the AD brain, $\mathrm{fA} \beta$ prepared in this manner displays typical Congo red birefringence under polarized light and is thioflavin S-positive, establishing that $\mathrm{A} \beta$ prepared in this manner has a fibrillar morphology (Kirschner et al., 1986, 1987; Evans et al., 1995). Additionally, fA $\beta$ prepared in this manner serves as a template for $A \beta$ deposition in vitro in a manner similar to $A \beta$ deposition onto authentic AD tissue amyloid (Esler et al., 1997). Preparations of $\mathrm{A} \beta$ not deliberately aggregated $(\mathrm{sA} \beta)$ did not display Congo red birefringence or thioflavin S staining.

Fibrillar $\mathrm{A} \beta$ prelabeled with thioflavin $\mathrm{S}$ was prepared from unlabeled $\mathrm{fA} \beta$ described above. Aliquots were thawed, centrifuged $(15,000 \times g ; 10$ $\mathrm{min})$, resuspended in $100 \mu \mathrm{l}$ of thioflavin S solution (1\% in distilled water; Sigma, St. Louis, MO), and allowed to incubate overnight on a shaking platform at $23^{\circ} \mathrm{C}$. The solution was then centrifuged as described above, and the $\mathrm{fA} \beta$ was resuspended and washed twice in $70 \%$ ethanol to remove excess dye. This thioflavin S-labeled $\mathrm{fA} \beta$ was then prepared for injection by resuspending, after the second ethanol wash, in sterile artificial CSF (aCSF; $128.6 \mathrm{~mm} \mathrm{NaCl}, 2.6 \mathrm{~mm} \mathrm{KCl}, 2.0 \mathrm{~mm} \mathrm{MgCl}_{2}$, and $1.4 \mathrm{mM} \mathrm{CaCl}_{2}, \mathrm{pH} 7.4$ ) to a total $\mathrm{A} \beta$ concentration of $10^{-4} \mathrm{M}$. Unlabeled fA $\beta$ was prepared for injection by pelleting the unstained fA $\beta$ as described above and resuspending in sterile aCSF at an $\mathrm{fA} \beta$ concentration of $10^{-4}$ M. Soluble $A \beta$ solution was prepared by dissolving $A \beta$ (Quality Control Biochemicals) in sterile water to a concentration of $10^{-4} \mathrm{M}$ and was stored at $-20^{\circ} \mathrm{C}$ in $100 \mu$ l aliquots until injection. No evidence of $\mathrm{A} \beta$ aggregation was observed in the $\operatorname{sA} \beta$ aliquots before or during the injection process.
Injection of $A \beta$ and preparation of brain tissue. Sprague Dawley rats (male; 200-250 gm; Harlan Sprague Dawley, Indianapolis, IN) were deeply anesthetized with sodium pentobarbital $(60 \mathrm{mg} / \mathrm{kg}$; Abbott Labs, Irving, TX) and then mounted in a small-animal stereotaxic instrument. The $\mathrm{fA} \beta$ solution $(10 \mu \mathrm{l})$ was injected stereotaxically into the striatum (anterior, $0.5 \mathrm{~mm}$; lateral, $3.0 \mathrm{~mm}$; and ventral, $6.5 \mathrm{~mm}$ ) using a 26 gauge needle (Fig. $1 A$ ). Stereotaxic coordinates were measured from bregma (Paxinos and Watson, 1986). Injections of vehicle or $10^{-4} \mathrm{M} \mathrm{sA} \beta(10 \mu \mathrm{l})$ were made into the contralateral striatum. Each $10 \mu$ linjection of fA $\beta$ contained $\sim 2400$ individual aggregates.

Seventy-five animals were used in the present study. Injections of either unlabeled or thioflavin S-prelabeled $\mathrm{fA} \beta$ were made into the striatum, with injections into the contralateral striatum of either sA $\beta$ or vehicle (aCSF or sterile water). The effects of $\mathrm{fA} \beta, \mathrm{sA} \beta$, and vehicle injections were analyzed $1,7,14$, and $30 \mathrm{~d}$ after injection $(n \geq 3$ for each treatment group). None of the animals used in the above experimental procedures showed signs of infection in the injection area before killing or after histological examination. Animals were group-housed with food and water available ad libitum in an American Association for Accreditation of Laboratory Animal Care-approved animal research facility. After the appropriate survival time, rats were killed by $\mathrm{CO}_{2}$ asphyxiation and then rapidly perfused through the ascending aorta with $200 \mathrm{ml}$ of PBS (3.0 $\mathrm{mM} \mathrm{Na}_{2} \mathrm{HPO}_{4}, 0.9 \mathrm{mM} \mathrm{KH}_{2} \mathrm{PO}_{4}$, and $154.0 \mathrm{~mm} \mathrm{NaCl}, \mathrm{pH} 7.4$; $23^{\circ} \mathrm{C}$ ) followed by $500 \mathrm{ml}$ of PBS containing $4 \%$ formaldehyde (Sigma, $4^{\circ} \mathrm{C}$ ). After perfusion, the brain was removed, blocked in the transverse plane, post-fixed in $4 \%$ formaldehyde $\left(4^{\circ} \mathrm{C} ; 1 \mathrm{~d}\right)$, and then placed in a $30 \%$ sucrose solution $\left(4^{\circ} \mathrm{C} ; 1 \mathrm{~d}\right)$. The brains were then serially sectioned at $20 \mu \mathrm{m}$ using a cryostat microtome (Model OTF/AS; Bright Instrument Co.) and collected in PBS.

Immunohistochemical examination of $A \beta$, glia, and neuronal markers. Immunohistochemical identification of $\mathrm{A} \beta$ was performed by washing sections in Tris-buffered saline (TBS; $140 \mathrm{~mm} \mathrm{NaCl}, 2.7 \mathrm{~mm} \mathrm{KCl}$, and $24.8 \mathrm{~mm}$ Tris base, $\mathrm{pH}$ 7.4) for $20 \mathrm{~min}$ and then in ethanol/distilled water (1:1) for $10 \mathrm{~min}$. Sections were washed three times for $10 \mathrm{~min}$ each in TBS, washed in blocking solution containing TBS and 10\% normal goat serum (NGS) for $30 \mathrm{~min}$, and then incubated overnight at $23^{\circ} \mathrm{C}$ in TBS containing $1 \%$ NGS and polyclonal anti-A $\beta$ (R1282; $1: 1500$; a kind gift from Dr. D. Selkoe) raised against uncoupled synthetic A $\beta 1-40$ (Haass et al., 1992). Sections were washed three times for $10 \mathrm{~min}$ each in TBS and then incubated $1 \mathrm{hr}$ at $23^{\circ} \mathrm{C}$ in TBS containing $1 \% \mathrm{NGS}$ and biotinylated donkey anti-rabbit IgG (1:500; Jackson ImmunoResearch, West Grove, PA). Sections were washed three times for $10 \mathrm{~min}$ each in TBS and then incubated $45 \mathrm{~min}$ at $23^{\circ} \mathrm{C}$ in TBS containing $1 \%$ NGS and fluorescein (FITC)-conjugated avidin (1:200; Jackson ImmunoResearch). Sections were washed three times for $10 \mathrm{~min}$ each in TBS, then mounted by floating onto gelatin-coated slides, and coverslipped using PBS/glycerol (1:1).

Immunohistochemical identification of microglia was performed by washing sections in blocking solution containing PBS and 1\% NGS for 30 min and then incubating overnight at $23^{\circ} \mathrm{C}$ in PBS containing $1 \%$ NGS and monoclonal anti-CD11b equivalent (OX-42; 1:10; Serotec, Indianapolis, IN). OX-42 is specific for the $\mathrm{C}_{3} \mathrm{~b}_{\mathrm{i}}$ complement protein receptor that is expressed in the CNS primarily, if not exclusively, by microglia. Sections were washed three times for 10 min each in PBS and then incubated $3 \mathrm{hr}$ at $23^{\circ} \mathrm{C}$ in PBS containing 1\% NGS and cyanine 3.18 (Cy3)-conjugated donkey anti-mouse IgG (1:600; Jackson ImmunoResearch). Sections were washed three times for $10 \mathrm{~min}$ each in PBS and then mounted and coverslipped as described above.

Immunohistochemical identification of astrocytes was performed by washing sections in blocking solution containing PBS, $1 \%$ NGS, and $0.3 \%$ Triton X-100 (Sigma) for $30 \mathrm{~min}$ and then incubating overnight at $23^{\circ} \mathrm{C}$ in PBS containing 1\% NGS, $0.3 \%$ Triton X-100, and either monoclonal or polyclonal anti-glial fibrillary acidic protein (GFAP; 1:400; Sigma). Sections were washed three times for $10 \mathrm{~min}$ each in PBS and then incubated $3 \mathrm{hr}$ at $23^{\circ} \mathrm{C}$ in PBS containing $1 \%$ NGS, $0.3 \%$ Triton X-100, and cyanine 5.18 (Cy5)-, Cy3-, or FITC-conjugated donkey anti-mouse or anti-rabbit IgG (Jackson ImmunoResearch) at concentrations of 1:600 (Cy3), 1:450 (Cy5), or 1:150 (FITC). Sections were washed three times for $10 \mathrm{~min}$ each in PBS and then mounted and coverslipped as described above.

Immunohistochemical identification of inducible nitric oxide synthase (iNOS) was performed by washing sections in blocking solution containing PBS and $10 \%$ bovine serum albumin (BSA; Sigma) for $1 \mathrm{hr}$ and then incubating overnight at $4^{\circ} \mathrm{C}$ in PBS containing $10 \%$ BSA and polyclonal anti-iNOS (1:200; Biomol, Plymouth Meeting, PA), which is specific for 

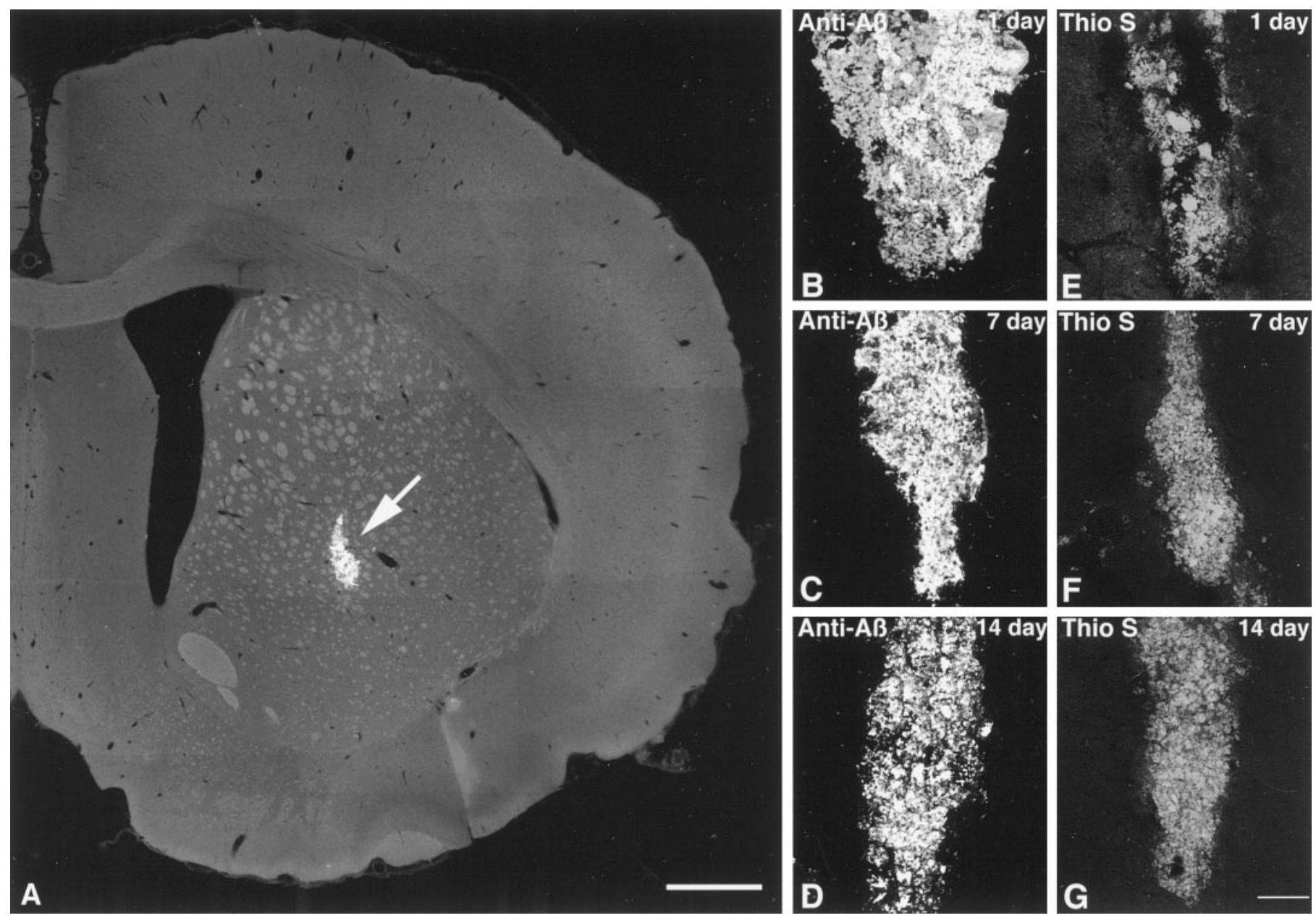

Figure 1. A, A confocal photomicrograph shows the location of $\mathrm{fA} \beta$ injection into the rat striatum. The fA $\beta$ shown here (arrow) was prelabeled with thioflavin $\mathrm{S}$ before injection anterior $0.5 \mathrm{~mm}$, lateral $3.0 \mathrm{~mm}$, and ventral $6.5 \mathrm{~mm}$ relative to bregma (Paxinos and Watson, 1986). The image was constructed from six optical sections acquired at $1.0 \mu \mathrm{m}$ intervals using a $4 \times$ lens. $B-G$, Fluorescent confocal images of injected fA $\beta$ in the striatum show that $\mathrm{fA} \beta$ is stable in vivo. $B-D$, Injected $\mathrm{fA} \beta$ is identified in tissue by labeling with anti-A $\beta$. $E-G$, Injected fA $\beta$ prelabeled with thioflavin $\mathrm{S}$ is also readily observable in the striatum. Note that, although variability in the shape of the injection site is evident in the images, there is little decrease in the total amount of injected $\mathrm{fA} \beta$ present over time. Also, no significant decrease in thioflavin S fluorescence is observed over time, suggesting injected fA $\beta$ monomers are not being replaced with endogenous rat $\mathrm{A} \beta$. Images were projected from six optical sections acquired at $1.0 \mu \mathrm{m}$ intervals using a $10 \times$ lens. Scale bars: $A, 1.0 \mathrm{~mm} ; B-G, 75 \mu \mathrm{m}$.

the iNOS $130 \mathrm{kDa}$ protein with no advertised cross-reactivity to endothelial nitric oxide synthase or neuronal nitric oxide synthase (nNOS). Cross-reactivity of the iNOS antibody was not tested in this study. Sections were washed three times for $10 \mathrm{~min}$ each in PBS and then incubated $3 \mathrm{hr}$ at $23^{\circ} \mathrm{C}$ in PBS containing $10 \%$ BSA and Cy3-conjugated donkey anti-rabbit IgG (1:600; Jackson ImmunoResearch). Sections were washed three times for 10 min each in PBS and then mounted and coverslipped as described above.

Immunohistochemical examination of parvalbumin, nNOS, and calbindin neurons were performed by washing sections in blocking solution containing PBS, $1 \%$ NGS, and $0.3 \%$ Triton X-100 (Sigma) for $30 \mathrm{~min}$ and then incubating overnight at $23^{\circ} \mathrm{C}$ in PBS containing $1 \%$ NGS, $0.3 \%$ Triton X-100, and either monoclonal anti-parvalbumin (1:1000; Sigma), polyclonal anti-nNOS (1:500; Chemicon, Temecula, CA), or monoclonal anti-calbindin (1:300; Sigma). Sections were washed three times for 10 min each in PBS and then incubated $3 \mathrm{hr}$ at $23^{\circ} \mathrm{C}$ in PBS containing $1 \%$ NGS, $0.3 \%$ Triton $\mathrm{X}-100$, and Cy3-conjugated donkey anti-mouse or anti-rabbit IgG (1:600; Jackson ImmunoResearch). Sections were washed three times for 10 min each in PBS and then mounted and coverslipped as described above.

Image analysis. Size characterization of $\mathrm{fA} \beta$ was done using a Leitz Orthoplan II microscope equipped for epifluorescence (Leitz, Wetzlar, Germany). Fibrillar $\mathrm{A} \beta$ was labeled with thioflavin $\mathrm{S}$ as described above; then $10 \mu \mathrm{l}$ of this solution was placed on a microscope slide, coverslipped, and visualized under fluorescence. The size distribution of 120 randomly selected fA $\beta$ aggregates was analyzed using the National Institutes of Health Image version 1.51 software program (National Institutes of Health, Bethesda, MD).

Immunofluorescence in brain tissue was examined using a MRC-1024 Confocal Imaging System equipped with a krypton/argon ion laser (Bio-Rad, Hercules, CA) in conjunction with an Olympus BX-75 microscope equipped for epifluorescence (Olympus Immunochemicals, Lake Success, NY). Labeled sections were imaged using filters appropriate for the specific visualization of fluorescein, cyanine 3.18 , and cyanine 5.18 (Brelje et al., 1993; Kennedy et al., 1994). Images were acquired using two different methods. The first method involved collecting multiple scans of optical sections (z-series) that were acquired at $1.0 \mu \mathrm{m}$ intervals. The second method involved collecting multiple scans of a single optical section using the Kalman imaging program, which allowed collection of low power confocal images while conserving the intensity and resolution of the original tissue staining. The optical sections were then projected into single images using image-processing software provided with the confocal system (Bio-Rad).

The total number of OX-42-immunoreactive microglia in $\mathrm{fA} \beta, \mathrm{sA} \beta$, or vehicle injection tracks was counted using confocal microscopy by optical sectioning $(2.0 \mu \mathrm{m}$ confocal z-series $)$ in $200 \times 300 \mu \mathrm{m}$ grids $\left(0.06 \mathrm{~mm}^{2}\right)$. 
Astrogliosis and iNOS expression were quantified using confocal microscopy by measuring the total GFAP or iNOS immunofluorescence over a similarly defined area. Data units for total immunofluorescence calculations are in gray scale pixel values, ranging from 0 (dark) to 255 (saturation level). Because individual astrocytes grouped closely together in the injection were impossible to count accurately, it was necessary to quantify astrocytes (GFAP) and iNOS expression using total fluorescence.

To determine whether microglia or astrocytes in the injection site contained phagocytized $\mathrm{fA} \beta$ or $\mathrm{sA} \beta$, we imaged $\mathrm{A} \beta$ and OX-42 immunofluorescence from the same tissue section simultaneously. The four experimental time points were compared by averaging the percentage of total glia in the measured area (defined above) that contained phagocytized $\mathrm{A} \beta$. Twenty-four animals were used for this analysis ( $n=3$ animals per treatment group at each time point; seven sections analyzed per animal). The average number of microglia in each confocal gridded section at $1,7,14$, and $30 \mathrm{~d}$ after injection was $20,57,73$, and 75 (fA $\beta$ ) and $20,61,33$, and $15(\mathrm{sA} \beta)$. Images of iNOS immunofluorescence with OX-42 or GFAP immunofluorescence were created using pairs of confocal images (iNOS + OX-42 and iNOS + GFAP) from the same tissue section. The pairs of images were imported using the National Institutes of Health Image version 1.51 software program, and the area of colocalization was computed by finding the regions of maximum signal overlap between the two images. To determine the percentage of microglia or astrocytes that express iNOS in the fA $\beta$ injection area, we counted iNOS-immunoreactive microglia or astrocytes using the confocal imaging system (area defined above).

To quantify neurons in and surrounding the defined $\mathrm{fA} \beta$ and $\operatorname{sA} \beta$ injection areas, we imaged GFAP immunofluorescence (marking the astrogliosis surrounding the $\mathrm{fA} \beta$ and $\mathrm{sA} \beta$ needle tracks) and parvalbumin, nNOS, or calbindin immunofluorescence on the same tissue sections simultaneously. Using a gridded eyepiece on a Leitz Orthoplan II microscope, we counted neurons in bins of increasing distance on both sides of the needle track at $10 \times$ magnification. The bins measured $0-125$, $126-250$, and $251-375 \mu \mathrm{m}$ outward (medial and lateral) from the margin of the GFAP-immunoreactive astrogliosis. Fifteen animals, with fA $\beta$ and sA $\beta$ injected contralaterally, were used for this analysis (total number of sections $=55$; total neurons counted within defined area, 862 [nNOS], 823 [parvalbumin], and 1529 [calbindin]). The total area of quantification was the same for each section.

Statistical analysis. All data are expressed as mean \pm SEM. One-way ANOVA was performed using the StatView statistical software program (Abacus Concepts, Calabasas, CA).

\section{RESULTS}

\section{Stability of fibrillar and soluble $\mathbf{A} \boldsymbol{\beta}$}

In the normal (noninjected) striatum or after injection of vehicle alone, no $\mathrm{A} \beta$ immunofluorescence, Congo red birefringence, or thioflavin $\mathrm{S}$ staining is observed at any time point. After injection of $\mathrm{sA} \beta, \mathrm{A} \beta$ immunofluorescence is only faintly visible and, when present, is almost invariably observed inside microglia immediately around the needle track at $1,7,14$, and $30 \mathrm{~d}$. At $1 \mathrm{~d}$ after $\mathrm{sA} \beta$ injection, 9\% of microglia within $150 \mu \mathrm{m}$ of the needle track contain anti-A $\beta$-immunoreactive material. By $30 \mathrm{~d}$ after injection, the percentage of microglia in the same area containing $\mathrm{A} \beta$ immunoreactive material increases to $19 \%$ (Fig. 2), but no difference in total $\mathrm{A} \beta$ immunofluorescence in the area surrounding the injection site is observed at any time point (data not shown). The $A \beta$-immunoreactive material detectable in microglia after sA $\beta$ injection does not display Congo red birefringence or thioflavin $\mathrm{S}$ staining at any time point, suggesting that this $\mathrm{A} \beta$ is present in a nonfibrillar form.

After injection of $\mathrm{fA} \beta$ or of $\mathrm{fA} \beta$ prelabeled with thioflavin $\mathrm{S}$ into the striatum, intense $\mathrm{A} \beta$ immunoreactivity or thioflavin $\mathrm{S}$ fluorescence, respectively, is present at 1,7 , and $14 \mathrm{~d}$ after injection. Although the shape of the individual $\mathrm{fA} \beta$ injection sites varied slightly between animals, no significant decrease in the quantity of $\mathrm{fA} \beta$ in the striatum is observed at these time points, as measured by $\mathrm{A} \beta$ immunofluorescence or thioflavin S fluores-

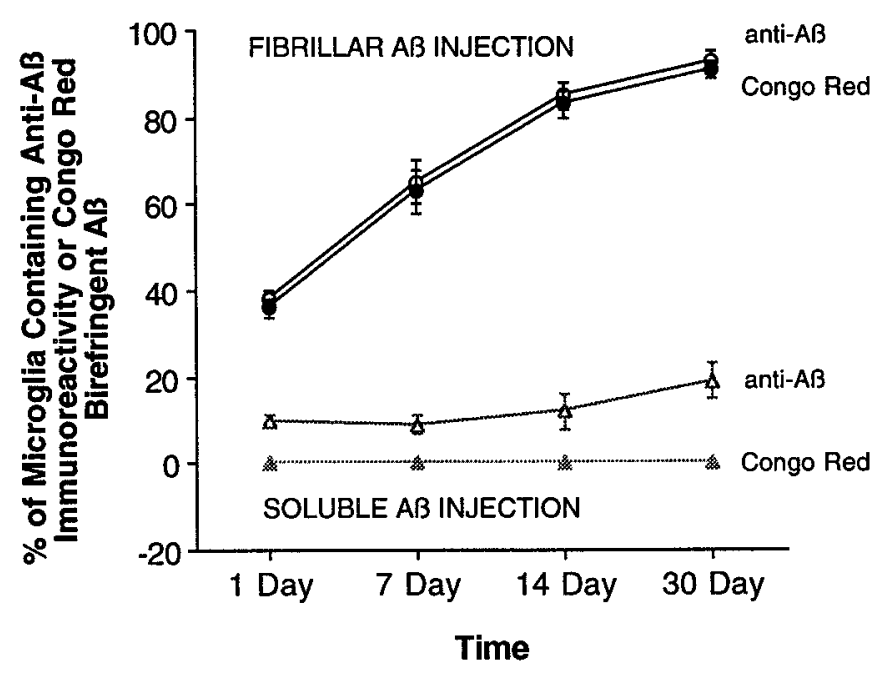

Figure 2. $\mathrm{A} \beta$ is phagocytized by microglia over time. Fluorescent confocal images of $\mathrm{fA} \beta$ (circles) or sA $\beta$ (triangles) labeled with anti-A $\beta$ were merged with confocal images of OX-42-immunoreactive microglia from the same tissue sections, allowing intracellular resolution and quantification of $\mathrm{A} \beta$ inside microglia. Microglia actively phagocytize fA $\beta$ over time, because $93 \%$ of microglia within $150 \mu \mathrm{m}$ of the fA $\beta$ needle track contain material that is both $A \beta$-immunoreactive and Congo red-birefringent at $30 \mathrm{~d}$ after injection. In contrast, a relatively small percentage of microglia $(10-20 \%)$ within $150 \mu \mathrm{m}$ of the $\mathrm{sA} \beta$ needle track contain $\mathrm{A} \beta$ immunoreactivity at the observed time points; this $\mathrm{A} \beta$-immunofluorescent material is neither Congo red-birefringent nor thioflavin S-positive (data not shown) and thus lacks the characteristics of fA $\beta$.

cence. Also, no decrease in thioflavin S fluorescence is observed, suggesting that the injected human $\mathrm{fA} \beta$ remains stable in vivo and is not exchanged for endogenous rat $\mathrm{A} \beta$ monomers at these time points (Fig. $1 B-G$ ). The $\mathrm{fA} \beta$ remains stable and detectable within the striatum up to at least $30 \mathrm{~d}$ after injection (Fig. 3 ) and displays typical Congo red birefringence under polarized light at all time points (data not shown). Although the overall quantity of $\mathrm{fA} \beta$ does not appear to decrease significantly after injection, there is a clear increase in the percentage of total $\mathrm{fA} \beta$ that is phagocytized and concentrated within microglia over time. At $1 \mathrm{~d}$ after injection, the majority of $\mathrm{fA} \beta$ remains in the extracellular space (Fig. 3A), although a significant minority of microglia (38\%) within $150 \mu \mathrm{m}$ of the needle track already contain phagocytized $\mathrm{fA} \beta$ at this time point (Fig. 2). With increasing time after injection, nearly all of the injected $\mathrm{fA} \beta$ is phagocytized and concentrated within microglia (Fig. $3 B, C$ ). By $30 \mathrm{~d}$ after injection, $93 \%$ of microglia within $150 \mu \mathrm{m}$ of the needle track contain phagocytized fA $\beta$ (Fig. 2).

\section{Glial responses to injections of fibrillar $A \beta$, soluble $A \beta$, or vehicle}

In the normal striatum, both microglia and astrocytes display a characteristic resting morphology. Microglia detectable using OX-42 immunoreactivity are evenly distributed throughout the striatum and possess long, thin, highly ramified processes connected to a cell body that has little observable cytoplasm (Barron, 1995). Astrocytes in the normal striatum that are GFAPimmunoreactive are also relatively evenly distributed, possessing a morphology characterized by a distinctly stellate-shaped cell body with little observable cytoplasm and long, thin radially extending processes (Eddleston and Mucke, 1993).

At $1 \mathrm{~d}$ after injection of vehicle alone, a large percentage of 

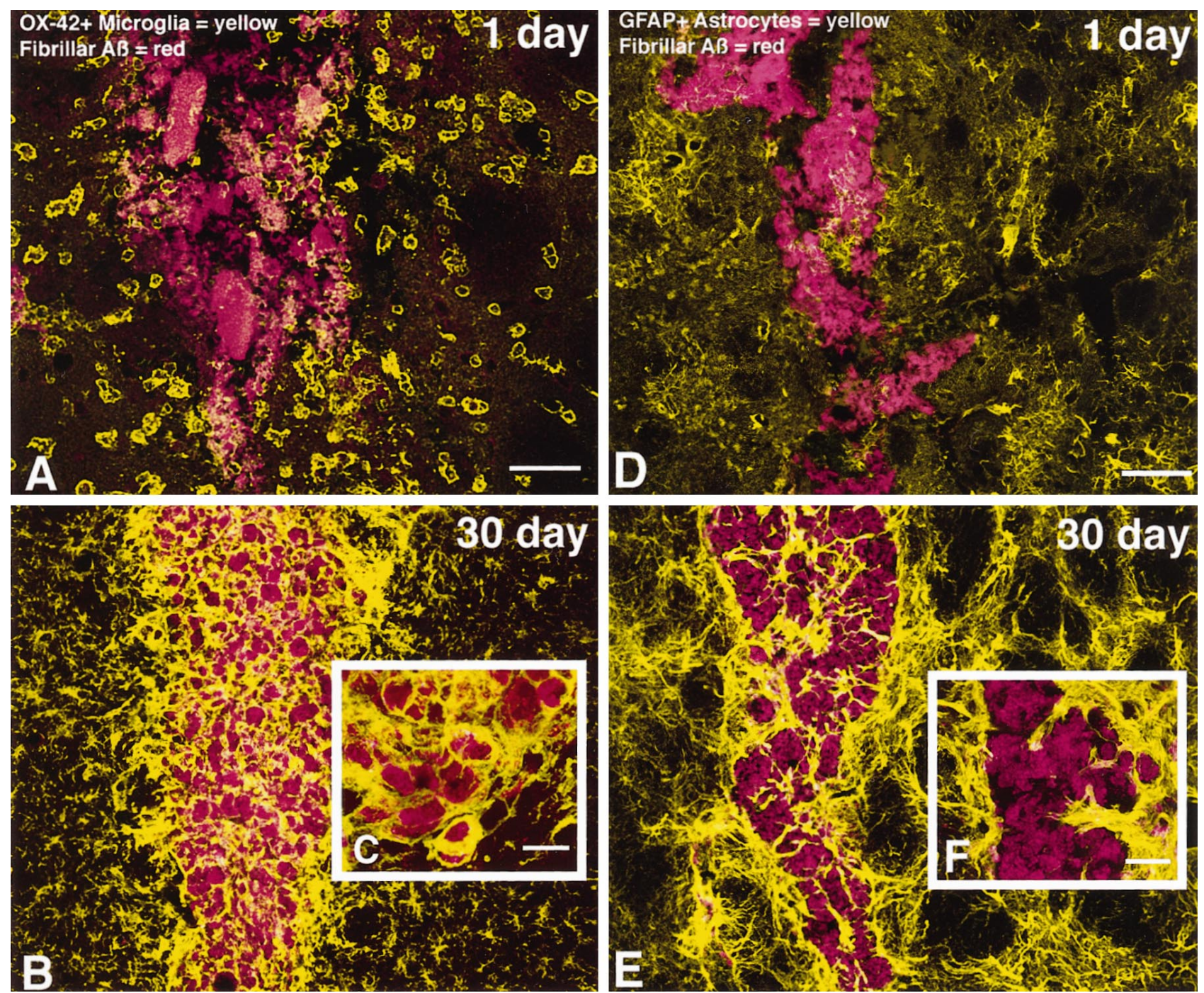

Figure 3. Fluorescent confocal images show that microglia actively phagocytize injected $\mathrm{fA} \beta$, whereas astrocytes wall-off $\mathrm{fA} \beta$-containing microglia from the surrounding neuropil. $A-C, \mathrm{fA} \beta$ prelabeled with thioflavin $\mathrm{S}$ appears red, and microglia labeled with anti-CD11b (OX-42) appear yellow. A, At $1 \mathrm{~d}$ after injection, activated microglia, characterized by short, thickened processes and marked cytoplasmic swelling, are observed surrounding injected fA $\beta$. Note that some of these microglia are associated with injected fA $\beta$ along the outer margins of the needle track. $B, C$, At $30 \mathrm{~d}$ after injection, fA $\beta$ is not cleared from the site of injection but rather is contained almost exclusively within microglia in the needle track. $D-F$, fA $\beta$ prelabeled with thioflavin $\mathrm{S}$ appears red, and astrocytes labeled with anti-GFAP appear yellow. D, At $1 \mathrm{~d}$ after injection, no significant astrogliosis is observed surrounding injected fA $\beta . E, F$, In contrast, a marked astrogliosis, characterized by activated astrocytes with swollen processes and increased GFAP immunofluorescence, is observed at $30 \mathrm{~d}$ after injection. Astrocytes are shown walling-off fA $\beta$-containing microglia from surrounding tissue. Images of fA $\beta$ and microglia or astrocytes were taken from the same double-labeled tissue sections. Images were projected from 12 optical sections acquired at $1.0 \mu \mathrm{m}$ intervals using a $10 \times$ or $40 \times$ lens. Scale bars: $A, B, D, E, 50 \mu \mathrm{m} ; C, F, 10 \mu \mathrm{m}$.

microglia surrounding the needle track have an activated morphology, characterized by short, thickened processes and marked cytoplasmic swelling (Barron, 1995). A gradient of microglial activation is observed at this time point, because nearly all microglia within $100 \mu \mathrm{m}$ of the needle track assume this activated morphology, whereas microglia that are $>150 \mu \mathrm{m}$ from the needle track display a resting morphology similar to that observed in the normal striatum. At $7 \mathrm{~d}$ after injection, nearly all microglia observed up to $300 \mu \mathrm{m}$ from the needle track possess an activated morphology. At the 14 and $30 \mathrm{~d}$ time points, the area showing microglial activation is significantly decreased, so that by $30 \mathrm{~d}$ after injection, only a thin line of activated microglia marking the needle track remain in the vehicle-injected striatum (Fig. 4A). This change in microglial morphology is mirrored by a change in the total number of microglia surrounding the needle track, which peaks at $7 \mathrm{~d}$ after injection and is followed by a gradual decline at days 14 and 30 (Fig. 5A). No differences in microglial morphology or number are observed at any time point when comparing vehicle injections of aCSF and sterile water.

Injection of vehicle alone also induces changes in the morphology and GFAP immunofluorescence of astrocytes surrounding the needle track. Astrocytes undergo a swelling of processes and show an increase in GFAP immunofluorescence, indicative of activation (Eddleston and Mucke, 1993; O'Callaghan et al., 1995). Evidence of astrocyte activation is faintly observable at $1 \mathrm{~d}$ after injection and is clearly evident at days 7 and 14 . At $30 \mathrm{~d}$ after injection, this astrocyte activation decreases so that only a thin line of activated astrocytes marking the needle track remain in the vehicle-injected striatum (Fig. 4C). This change in astrocyte morphology is mirrored by a change in GFAP immunofluorescence, which peaks at 

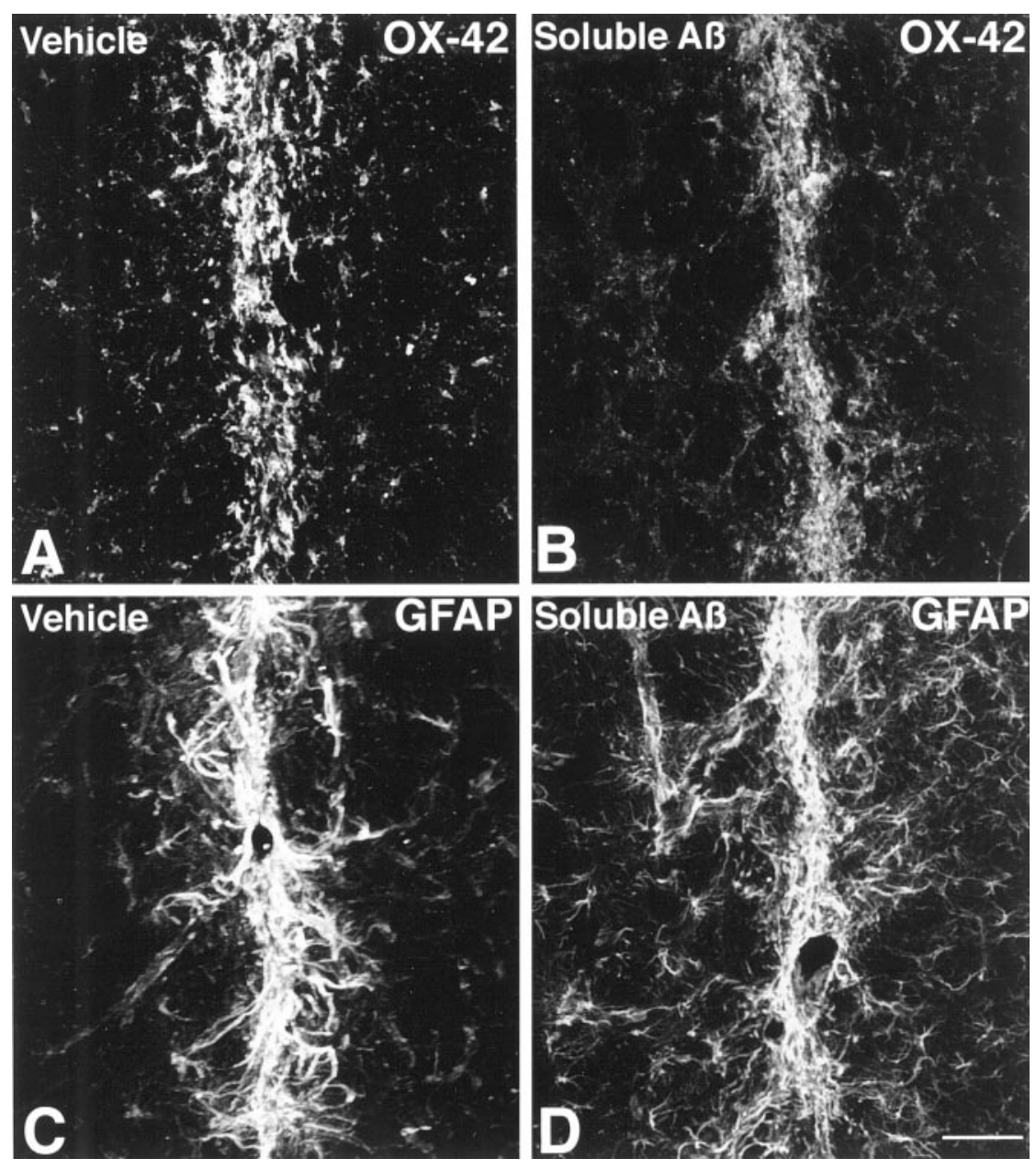

Figure 4. Microglia and astrocyte responses $30 \mathrm{~d}$ after vehicle or sA $\beta$ injection are shown. $A, B$, No difference in OX-42 immunofluorescence is observed in the needle track after vehicle or $\mathrm{sA} \beta$ injection. $C, D$, Similarly, no difference in GFAP immunofluorescence is observed in the needle track after vehicle or $\mathrm{sA} \beta$ injection. Images are Kalman averages of a single optical section acquired using a $20 \times$ lens. Scale bar, $50 \mu \mathrm{m}$.

$14 \mathrm{~d}$ after injection and is followed by a marked decline at day 30 (Fig. 5B). No differences in astrocyte morphology or GFAP fluorescence are observed at any time point when comparing vehicle injections of aCSF and sterile water.

Striatal injection of $\mathrm{sA} \beta$ induces microglial and astrocyte changes that are nearly indistinguishable from those observed after injection of vehicle alone. However, one significant difference between the injection of $\mathrm{sA} \beta$ and vehicle is that although vehicle injection alone never induces any detectable accumulation of $\mathrm{A} \beta$, injection of $\mathrm{sA} \beta$ results in accumulation of anti-A $\beta$ immunoreactivity in $\sim 10-20 \%$ of microglia in the needle track at the time points examined (Fig. 2). Those microglia that contain $\mathrm{A} \beta$ immunoreactivity invariably have an activated morphology and maintain this morphology up to at least $30 \mathrm{~d}$ after injection. Even with the presence of microglia containing $\mathrm{A} \beta$ immunoreactivity after sA $\beta$ injection, only a thin line of activated microglia and astrocytes, similar in appearance to the vehicle-injected striatum, remain at $30 \mathrm{~d}$ after $\mathrm{sA} \beta$ injection (Fig. 4B,D). Neither the number of microglia nor the GFAP immunofluorescence surrounding the needle track differs significantly at any time point when comparing sA $\beta$ with vehicle injection (Fig. $5 A, B$ ).

Injection of $\mathrm{fA} \beta$ induces several changes in microglia and astrocytes that are significantly different from those observed after injection of either vehicle or $\mathrm{sA} \beta$. The earliest difference observed when comparing $\mathrm{fA} \beta$ and $\operatorname{sA} \beta$ injection sites is in the percentage of microglia that contain $A \beta$ immunoreactivity. At $1 \mathrm{~d}$ after injection of $\mathrm{fA} \beta, 38 \%$ of microglia within $150 \mu \mathrm{m}$ of the needle track contain phagocytized $\mathrm{fA} \beta$. The percentage of microglia containing fA $\beta$ continues to rise until day 30, at which point $93 \%$ of microglia in the same area contain detectable concentrations of $\mathrm{A} \beta$ immunoreactivity (Figs. 2, 3). At all time points examined, microglia that contain $\mathrm{fA} \beta$ invariably have an activated morphology. No significant increase in astrocyte activation is observed at $1 \mathrm{~d}$ after $\mathrm{fA} \beta$ injection (Fig. 3D). However, at $30 \mathrm{~d}$ after injection, a marked astrogliosis, characterized by activated astrocytes with swollen processes and increased GFAP immunofluorescence, is observed in the $\mathrm{fA} \beta$ injection area. A virtual wall of activated, GFAP-immunoreactive astrocytes is observed surrounding the fA $\beta$-containing microglia at $30 \mathrm{~d}$ after injection (Fig. 3E,F). Although changes in the number of microglia and in the GFAP immunofluorescence induced by injection of fA $\beta$ may initially be masked by changes induced by the damage associated with needle placement alone, there are significantly greater numbers of microglia within $150 \mu \mathrm{m}$ of the needle track after fA $\beta$ compared with $\mathrm{sA} \beta$ or vehicle injection at days 14 and 30 (Fig. 5A). Similarly, there is a significantly greater concentration of GFAP immunofluorescence within $150 \mu \mathrm{m}$ of the needle track after $\mathrm{fA} \beta$ compared with $\mathrm{sA} \beta$ or vehicle injection at day 30 (Fig. 5B).

\section{Fibrillar A $\beta$ induces iNOS expression in microglia and astrocytes}

In the normal striatum, $<20 \%$ of the microglia and $<5 \%$ of astrocytes display iNOS immunoreactivity, and those microglia 

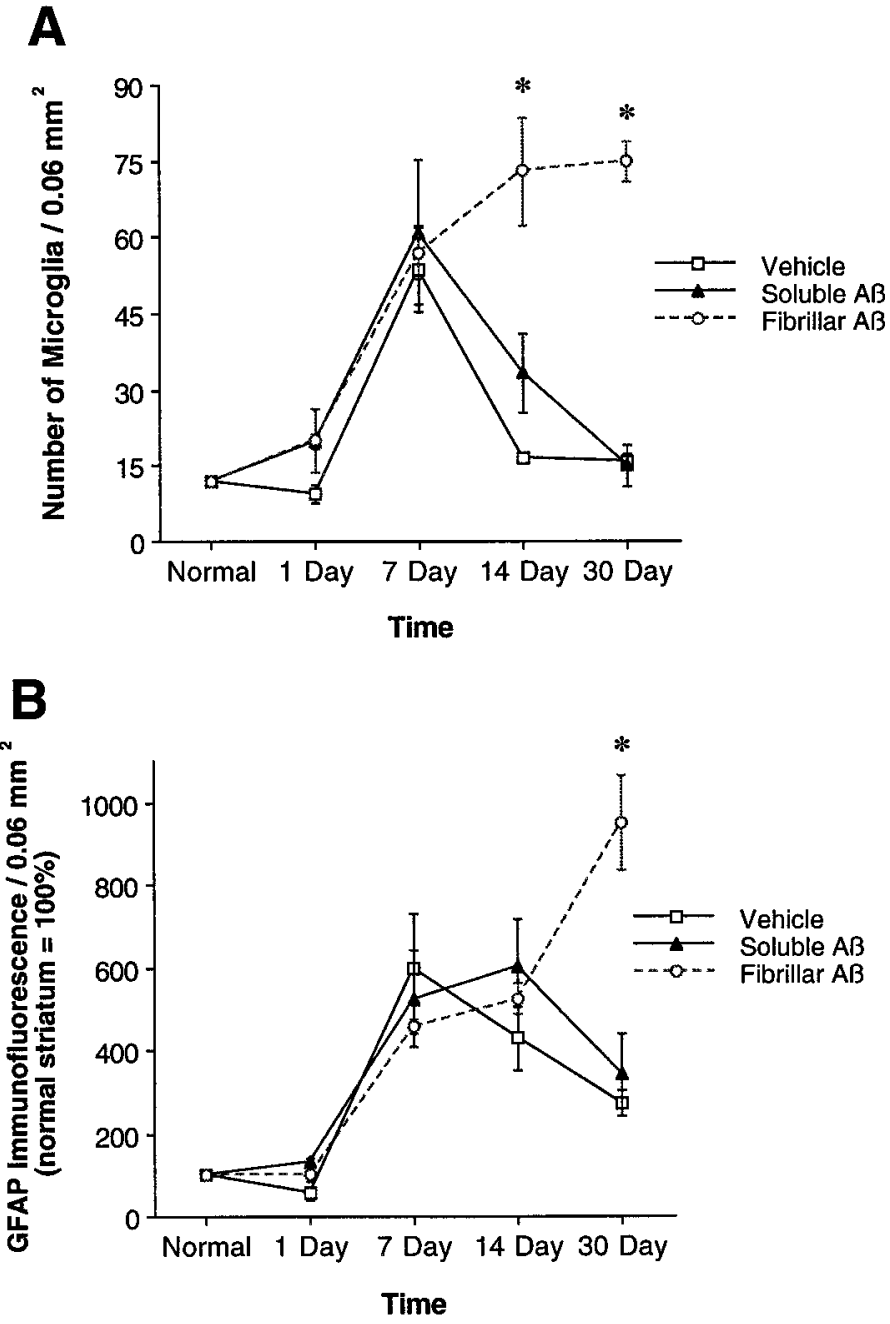

Figure 5. Injected fA $\beta$ induces a larger and more-sustained gliosis compared with that seen with injected $\mathrm{sA} \beta$ or vehicle alone. $A$, The number of OX-42-immunoreactive microglia, quantified in $0.06 \mathrm{~mm}^{2}$ grids centered on $\mathrm{fA} \beta$ (open circles), sA $\beta$ (closed triangles), or vehicle (open squares) needle tracks, is similar at 1 and $7 \mathrm{~d}$ after injection but is significantly increased in the $\operatorname{fA} \beta$ injection area relative to the $\operatorname{sA} \beta$ and vehicle injection areas at 14 and $30 \mathrm{~d}$ after injection. Note that at $1 \mathrm{~d}$ after injection, the number of microglia in the $\mathrm{fA} \beta, \mathrm{sA} \beta$, or vehicle injection area does not differ significantly from the number of microglia present in a comparable area of normal striatum. $B$, Astrogliosis, measured by computing the total intensity of GFAP immunofluorescence in $0.06 \mathrm{~mm}^{2}$ grids centered on $\mathrm{fA} \beta$ (open circles), $\mathrm{AA} \beta$ (closed triangles), or vehicle (open squares) needle tracks, is similar at 1, 7, and $14 \mathrm{~d}$ after injection. At $30 \mathrm{~d}$ after injection, GFAP immunofluorescence is significantly increased in the $\mathrm{fA} \beta$ injection area relative to the $\mathrm{sA} \beta$ and vehicle injection areas. Images used for microglia counts and GFAP immunofluorescence measurements were Kalman averages of a single optical section acquired using a $10 \times$ lens $(* \mathrm{fA} \beta$ vs $\mathrm{sA} \beta$ or vehicle, both $p<0.05)$.

and astrocytes that do express iNOS do so at low levels. Within $150 \mu \mathrm{m}$ of the needle track, there is a significant increase in iNOS immunofluorescence above those levels observed in the normal striatum at $30 \mathrm{~d}$ after vehicle (64\% increase) or sA $\beta(75 \%$ increase) injection, but this difference between vehicle and $\operatorname{sA} \beta$ injection did not reach statistical significance (data not shown). Those microglia and astrocytes that express iNOS at $30 \mathrm{~d}$ after vehicle or $\mathrm{sA} \beta$ injection seem to be from the same small population of microglia and astrocytes that remain activated and mark the thin line of the needle track. No increase in iNOS immuno-

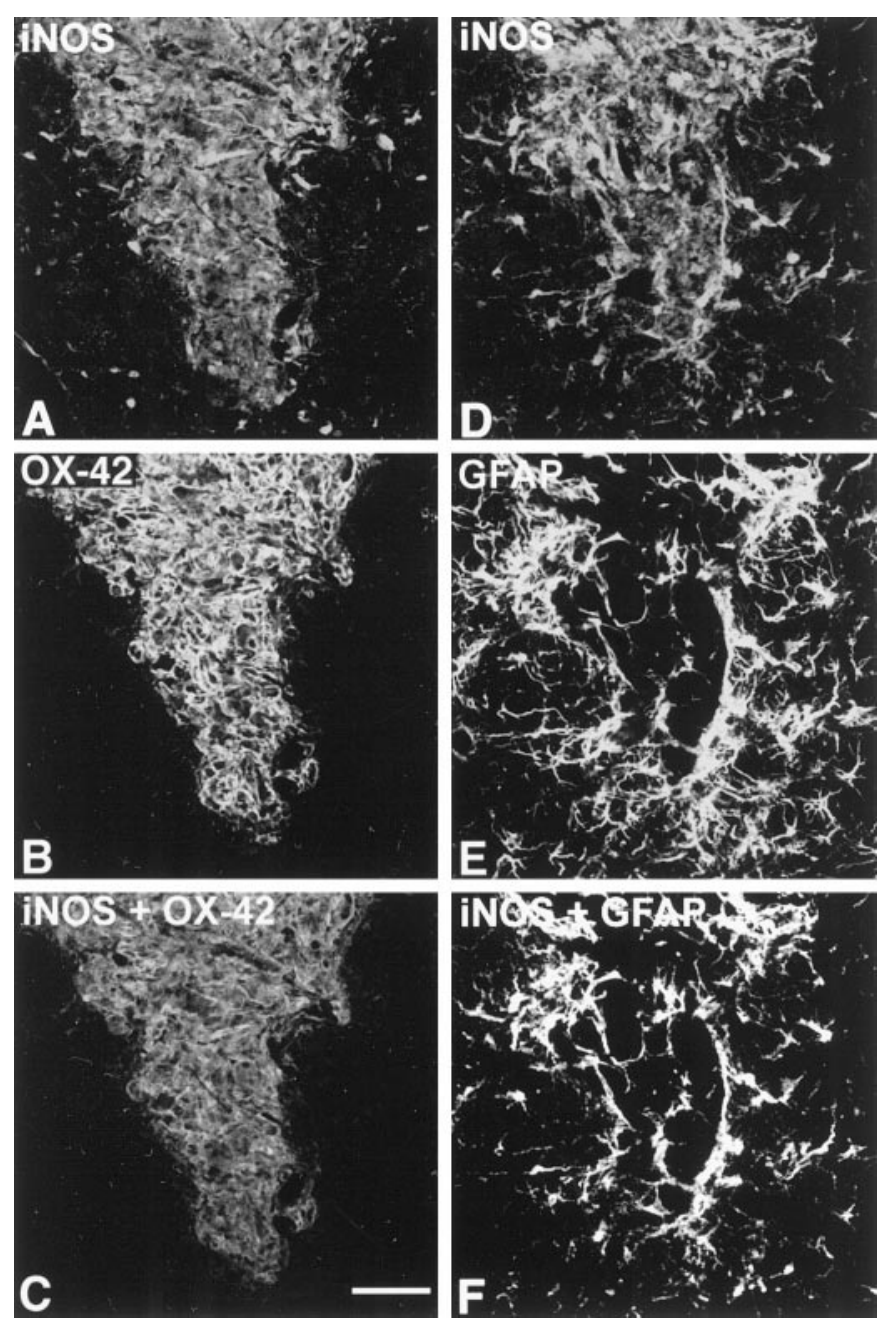

Figure 6. iNOS expression by microglia and astrocytes is increased $30 \mathrm{~d}$ after fA $\beta$ injection. $A, B, D, E$, Tissue sections were labeled with antiiNOS and with either OX-42 or anti-GFAP. $C, F$, Using the National Institutes of Health Image 1.51 software program, we merged iNOS and OX-42 or GFAP images, and the area of maximum signal overlap between the images was computed to show immunofluorescence colocalization. Note that microglia in the $\mathrm{fA} \beta$ injection area, which were shown in Figure 3 to contain $\mathrm{fA} \beta$, also express iNOS at $30 \mathrm{~d}$ after injection, whereas most microglia outside the injection area do not. Also note that only those astrocytes forming a virtual wall around the injected area, within $100 \mu \mathrm{m}$ of the $\mathrm{A} \beta$-containing microglia, express high levels of iNOS. The iNOS, OX-42, and GFAP images were taken from the same double-labeled tissue sections and are Kalman averages of a single optical section acquired using a $10 \times$ lens. Scale bar, $50 \mu \mathrm{m}$.

fluorescence above the level in the normal striatum is observed in tissue areas outside of the vehicle or $\mathrm{sA} \beta$ needle tracks.

Compared with that in the normal striatum, iNOS immunofluorescence is $121 \%$ higher within $150 \mu \mathrm{m}$ of the needle track at $30 \mathrm{~d}$ after $\mathrm{fA} \beta$ injection. Injection of $\mathrm{fA} \beta$ also promotes an increase in iNOS expression that significantly exceeds the iNOS expression observed after vehicle or $\mathrm{sA} \beta$ injection (data not shown). Simultaneous imaging of iNOS and OX-42 or GFAP immunofluorescence on the same tissue sections confirms that $\mathrm{fA} \beta$ induces iNOS expression in both microglia and astrocytes (Fig. 6). At $30 \mathrm{~d}$ after injection, nearly $100 \%$ of microglia that contain phagocytized fA $\beta$ are also iNOS-immunoreactive. Similarly, nearly $100 \%$ of astrocytes within $100 \mu \mathrm{m}$ of microglia 
containing $\mathrm{A} \beta$ are iNOS-immunoreactive. Outside of this area, iNOS expression closely resembles that of the normal striatum described above.

\section{Fibrillar $A \beta$-induced loss of specific neuronal populations}

To determine the effects of $\mathrm{fA} \beta$ and $\mathrm{sA} \beta$ injections on striatal neurons, we labeled a population of projection neurons using anti-calbindin and two distinct populations of interneurons using anti-parvalbumin and anti-nNOS. Spiny projection neurons represent $\sim 90 \%$ of total neurons in the striatum, and aspiny interneurons represent $\sim 10 \%$. Calbindin labels nearly all projection neurons, whereas among interneurons, parvalbumin labels 40$50 \%$, and nNOS labels 10-20\% (Kawaguchi et al., 1995). These three antibodies label distinct subpopulations of neurons, with only a small percentage of interneurons showing colocalization of calbindin and nNOS immunoreactivity (Bennett and Bolam, 1993). The numbers of parvalbumin-, nNOS-, and calbindinimmunoreactive neurons were compared in tissue areas surrounding injected $\mathrm{fA} \beta$ and $\mathrm{sA} \beta$ at $30 \mathrm{~d}$ after injection and in the normal (noninjected) striatum (Figs. 7, 8). Compared with levels in both the $\mathrm{sA} \beta$ injection area and the normal striatum, a significant decrease in the number of parvalbumin-immunoreactive neurons is observed in the areas $0-125 \mu \mathrm{m}$ (51\% reduction) and $126-250 \mu \mathrm{m}$ (24\% reduction) from the margin of the astrogliosis surrounding the injected fA $\beta$ (Figs. 7, 8). Similarly, fA $\beta$ induces a significant decrease in nNOS-immunoreactive neurons in the area $0-125 \mu \mathrm{m}$ from the margin of the injection track compared with both the sA $\beta$ injection area and the normal striatum (46\% reduction). In contrast, no significant decrease in the number of calbindin-immunoreactive neurons is observed in tissue areas surrounding $\mathrm{fA} \beta$ or $\mathrm{sA} \beta$ injection compared with the normal striatum (Fig. 8).

\section{DISCUSSION}

\section{Stability of fibrillar $A \beta$ in the rat CNS in vivo}

In the present study, injected $\mathrm{fA} \beta$ is remarkably stable in the rat CNS in vivo, contrasting with previous reports that noted an apparent lack of $A \beta$ stability after injection or infusion. An early review of AD animal models (Price et al., 1992) reported that $\mathrm{sA} \beta$ or its fragments injected into various brain regions were either neurotoxic, nontoxic, or neurotrophic depending on the aggregation state of the peptide. One consistent feature of these studies, however, was the difficulty encountered in visualizing $\mathrm{A} \beta$ after injection of $\mathrm{sA} \beta$. In the present study, $\mathrm{sA} \beta$ was not stable in vivo, appearing to be cleared rapidly from the site of injection. Rapid clearance of $\mathrm{sA} \beta$ may also explain the inability to visualize injected $\mathrm{A} \beta$ in the previous studies.

Aggregates of injected $\mathrm{fA} \beta$, which are of comparable size to AD plaque cores found in the human brain, are highly stable in the present study. The stability of $\mathrm{fA} \beta$ contrasts with a previous study that showed that human AD plaque cores injected into the rat brain were cleared by microglia from their site of injection within $30 \mathrm{~d}$ (Frautschy et al., 1992). This difference in stability between $\mathrm{fA} \beta$ and $\mathrm{AD}$ plaque cores may be explained in part by the presence of a variety of extracellular, non- $\mathrm{A} \beta$ components in the plaque cores obtained from humans. For example, complement proteins $\mathrm{C} 1 \mathrm{q}, \mathrm{C} 4 \mathrm{~d}$, and $\mathrm{C} 3 \mathrm{~d}$, which help facilitate phagocytosis of foreign material by macrophages and microglia, are bound to $\mathrm{A} \beta$ in $\mathrm{AD}$ plaques (McGeer and McGeer, 1996). The presence of these proteins and other non- $\mathrm{A} \beta$ components in the injected plaque cores may explain their rapid clearance from the rat brain in the previous study. In contrast, injected fA $\beta$ aggregates that remain stable in the rat striatum up to $30 \mathrm{~d}$ after injection are composed of synthetic $\mathrm{A} \beta$ without any non- $\mathrm{A} \beta$ components.

\section{Injection of fibrillar $\mathbf{A} \boldsymbol{\beta}$ induces a differential response in microglia and astrocytes}

In the present study, fA $\beta$ of a known quantity, size range, and fibrillar character was injected into one striatum, with injections of $\mathrm{sA} \beta$ or vehicle made into the contralateral striatum. Using this model system, we demonstrate that $\mathrm{fA} \beta$ alone is sufficient to induce a marked gliosis and iNOS induction in microglia and astrocytes in the rat brain in vivo. Although it cannot be excluded that, once in the brain, $\mathrm{A} \beta$ may be interacting with other endogenous, plaque-associated components to exert its effects, our results demonstrate that injection of synthetic fA $\beta$ alone is sufficient to cause an increase in iNOS expression and to induce a marked gliosis similar to that observed in the human AD brain (Itagaki et al., 1989; Uchihara et al., 1995). Previous reports have suggested that iNOS expression may serve as an index of reactive gliosis (Murphy et al., 1993; Brosnan et al., 1994); thus, the present results strongly suggest that injection of fA $\beta$ activates both microglia and astrocytes. One surprising observation in the present study is a low level of iNOS immunoreactivity present in a small minority of microglia and astrocytes in the normal (noninjected) striatum. A recent study (Wong et al., 1996) reported no detectable iNOS gene expression in the normal (noninduced) rat brain. The low level of iNOS immunoreactivity in the normal striatum may be caused by slight cross-reactivity between the iNOS antibody and other agents in the striatum.

In contrast to injections of $\mathrm{fA} \beta$, contralateral injection of $\mathrm{sA} \beta$ produces no significant increase in gliosis and iNOS expression above that observed for injection of vehicle alone. One reason for the lack of $\mathrm{sA} \beta$-induced gliosis may be that $\mathrm{sA} \beta$ is rapidly cleared from brain parenchyma, suggested here by the fact that $30 \mathrm{~d}$ after $\mathrm{sA} \beta$ injection, $\mathrm{A} \beta$ immunofluorescence is only detected in a minority of microglia surrounding the needle track. The total amount of $\mathrm{A} \beta$ present within these microglia is a small fraction of the total $\mathrm{sA} \beta$ originally injected. Furthermore, the $\mathrm{A} \beta$ present in microglia is neither Congo red-birefringent nor thioflavin $\mathrm{S}$-positive, suggesting that it is not in a fibrillar form. Together, these results suggest that although $\mathrm{sA} \beta$ may be neurotoxic in vitro, in the rat $\mathrm{CNS}$ in vivo, injected $\mathrm{sA} \beta$ is cleared rapidly and does not induce a sustained glial response that characterizes acute and subchronic neurotoxicity (Gramsbergen and van den Berg, 1994; O'Callaghan et al., 1995).

Although both microglia and astrocytes show a dramatic upregulation of iNOS expression in response to injection of $\mathrm{fA} \beta$, there are marked spatial and morphological differences in the microglia and astrocyte responses to $\mathrm{fA} \beta$. Whereas microglia surround and phagocytize fA $\beta$, astrocytes show no evidence of $\mathrm{A} \beta$ phagocytosis but rather form a virtual wall between microglia containing fA $\beta$ and the surrounding neurons. Previous studies of human AD tissue (Itagaki et al., 1989; Uchihara et al., 1995) and the brains of mice overexpressing a mutant APP gene (Games et al., 1995) have also noted that reactive microglia are concentrated toward the center of $\mathrm{AD}$ plaques, whereas reactive astrocytes are present at the margins of plaques. Microglia containing intracellular A $\beta$ have been noted in AD brain (Akiyama et al., 1996), but these microglia lack detectable mRNA encoding $\mathrm{A} \beta$, suggesting an extracellular $\mathrm{A} \beta$ origin (Scott et al., 1993). Similar findings 

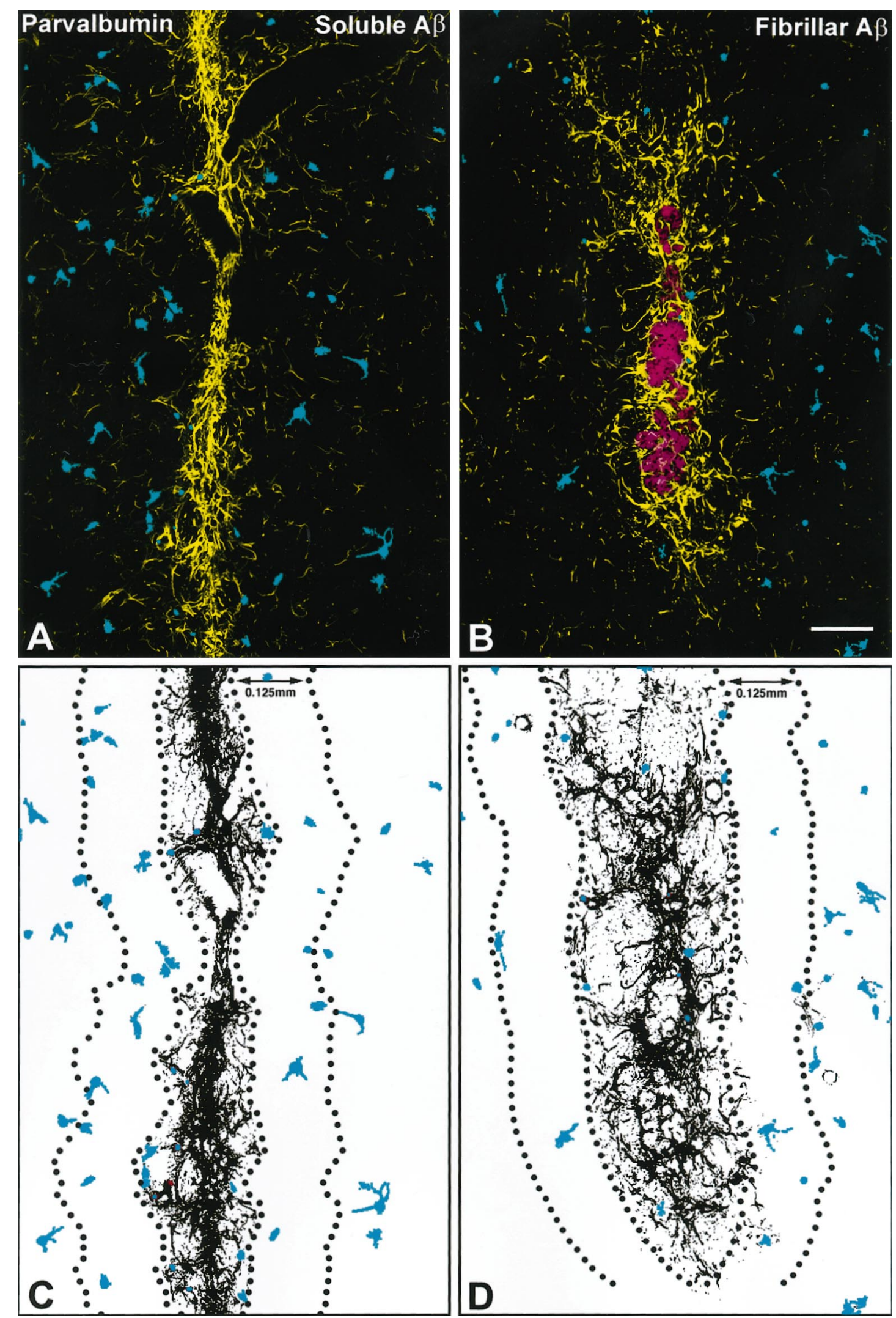

Figure 7. Injection of $\mathrm{fA} \beta$ induces a reduction in the number of parvalbumin-immunoreactive neurons. $A, B$, Anti-parvalbumin and anti-GFAP were used to label parvalbumin neurons (blue) and the astrogliosis ( yellow) surrounding sA $\beta$ and fA $\beta$ needle tracks. $A, C$, Note that in tissue areas surrounding injected sA $\beta$, parvalbumin neurons are evenly distributed outward from the margin of the astrogliosis. $B, D$, In contrast, a significant reduction in the number of parvalbumin neurons is observed near the astrogliosis surrounding injected fA $\beta$ (red; image of fA $\beta$ from a serial section labeled with anti-A $\beta$ ). Images of parvalbumin neurons and astrocytes were taken from the same double-labeled tissue sections and are Kalman averages of a single optical section acquired using a $10 \times$ lens. Scale bar, $125 \mu \mathrm{m}$. 
have also been noted in vitro, where microglia have been shown to scavenge and accumulate $\mathrm{A} \beta$ intracellularly (Frackowiak et al., 1992; Shaffer et al., 1995; Ard et al., 1996; Paresce et al., 1996), whereas astrocytes envelop and wall-off fA $\beta$ (Canning et al., 1993; Pike et al., 1994; DeWitt and Silver, 1996).

\section{A $\beta$-induced neuronal loss}

In the current study, no significant difference in the number of calbindin-immunoreactive projection neurons was observed when comparing $\mathrm{fA} \beta$ and $\mathrm{sA} \beta$ injection areas and the normal striatum. In the AD striatum, the density of calbindin neurons has been

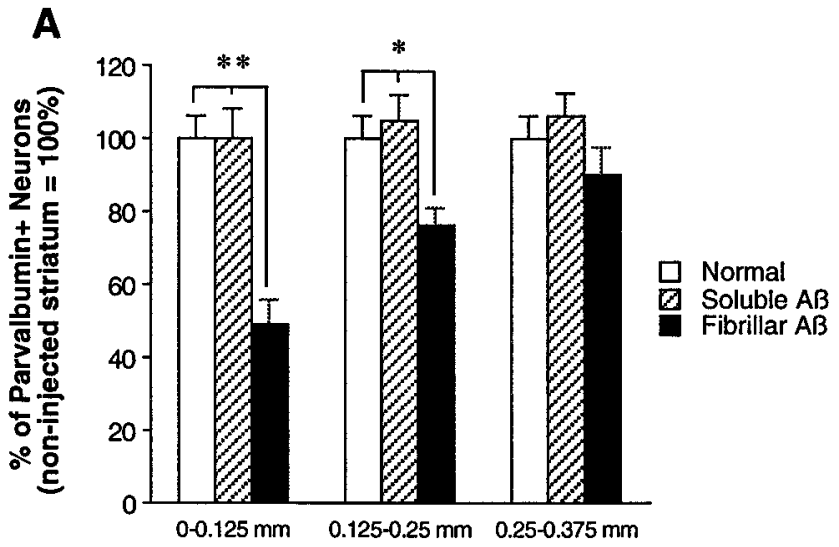

Distance from Injection Track

B

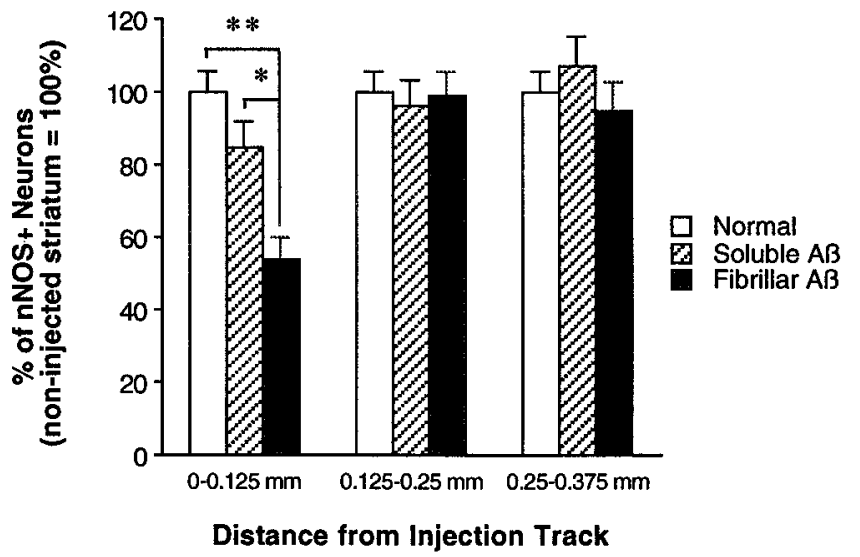

C

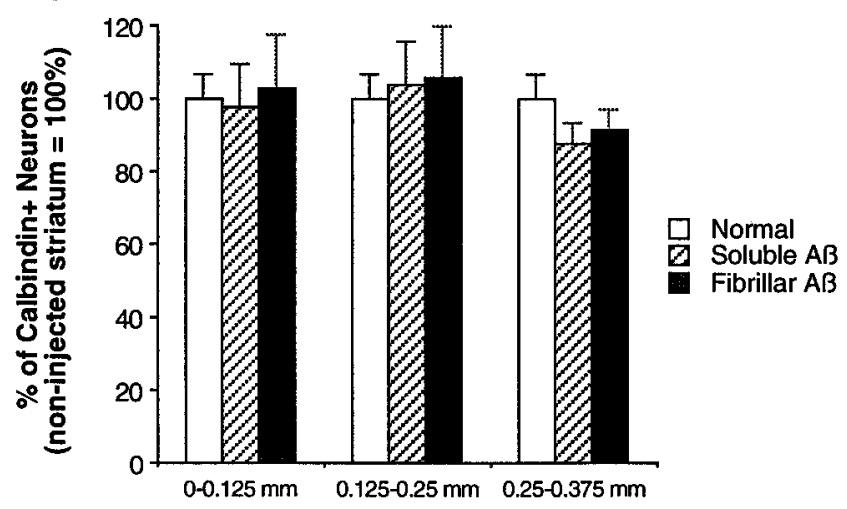

Distance from Injection Track shown previously not to differ significantly from that of normal controls (Selden et al., 1994). The current findings differ, however, from previous studies that showed a decrease in calbindin immunoreactivity in AD versus normal cortex (Ferrer et al., 1993; Nishiyama et al., 1993). In contrast, the number of parvalbuminand nNOS-immunoreactive interneurons in the current study is significantly reduced in the $\mathrm{fA} \beta$ injection area compared with the $\mathrm{sA} \beta$ injection area and the normal striatum. Previous studies have shown that parvalbumin neurons in the rat striatum are more sensitive to excitotoxic injury than are calbindin neurons (Waldvogel et al., 1991). Although the results of the current study strongly suggest that $\mathrm{fA} \beta$ induces a selective loss of neurons in the rat striatum, this effect could also be explained by a selective downregulation of parvalbumin and nNOS in neurons surrounding the injected $\mathrm{fA} \beta$. $\mathrm{A} \beta 1-40$, the peptide length examined in the present study, has also been shown to cause glial-induced inhibition of neurite outgrowth in vitro (Canning et al., 1993) and to reduce numbers of choline acetyltransferase-immunoreactive neurons after injection in vivo (Giovannelli et al., 1995).

\section{Mechanisms of $\mathbf{A} \boldsymbol{\beta}$ toxicity}

After injection of $\mathrm{fA} \beta$, microglia and astrocytes rapidly separate $\mathrm{fA} \beta$ from the surrounding neuropil, suggesting that $\mathrm{A} \beta$-induced neurotoxicity may not result from direct contact between $\mathrm{A} \beta$ fibrils and surrounding neurons. If $\mathrm{fA} \beta$ is not directly toxic to neurons, how might the intervening glia mediate fA $\beta$ toxicity? Recent studies have demonstrated that the receptor for advanced glycation end products (RAGE) and class A and B scavenger receptors on microglia bind $\mathrm{A} \beta$, which leads to microglial activation (El Khoury et al., 1996; Paresce et al., 1996; Yan et al., 1996). Glial activation, in turn, results in enhanced expression of a variety of bioactive molecules, including neurotoxic phenolic amines, cytokines, growth factors, protease inhibitors, adhesion molecules, and nitric oxide (Boje and Arora, 1992; Dickson et al., 1992; Ishii and Haga, 1992; Haga et al., 1993; Giulian et al., 1995; Mrak et al., 1995). Of particular interest is a recent study (Giulian et al., 1996) showing that human $A \beta 1-40$ and $A \beta 1-42$, but not rodent $\mathrm{A} \beta$, induce microglial adherence of $\mathrm{A} \beta$ and killing of neurons in vitro. This finding, together with those of the present study in vivo, underscores the importance of using the human $\mathrm{A} \beta$ peptide to induce neuronal toxicity in rodent models of AD.

$\mathrm{A} \beta$-induced NOS expression and NO production in cultured microglia and macrophages have also been reported previously (Klegeris et al., 1994; Goodwin et al., 1995; Meda et al., 1995), and NOS induction has also been linked to neuronal impairment

$\leftarrow$

Figure 8. Injected $\mathrm{fA} \beta$ induces a reduction in the number of parvalbumin- and nNOS- but not calbindin-immunoreactive neurons. $A-C$, Subpopulations of striatal neurons were labeled on separate tissue sections using anti-parvalbumin, anti-nNOS, or anti-calbindin, and on all sections the needle track was double-labeled using anti-GFAP. Numbers of parvalbumin-, nNOS-, and calbindin-immunoreactive neurons are compared over identical areas around $\mathrm{sA} \beta$ and fA $\beta$ needle tracks at $30 \mathrm{~d}$ after injection and in the normal (noninjected) striatum. $A$, A significant reduction in the number of parvalbumin-immunoreactive neurons is observed up to $250 \mu \mathrm{m}$ from the margin of the fA $\beta$ injection track relative to the $\mathrm{sA} \beta$ injection track and normal striatum. $B$, In the fA $\beta$ injection area, a significant reduction is also observed in the number of nNOSimmunoreactive neurons up to $125 \mu \mathrm{m}$ from the injection track relative to the $\mathrm{sA} \beta$ injection track and normal striatum. $C$, In contrast, no significant difference in the number of calbindin-immunoreactive neurons is observed when comparing $\mathrm{fA} \beta$ and $\mathrm{sA} \beta$ injection areas and the normal striatum. $(* * p<0.01 ; * p<0.05)$ 
and death in several neurological disorders involving multiple sclerosis and acquired immunodeficiency syndrome dementia (Bo et al., 1994; Adamson et al., 1996). The present study demonstrates that $\mathrm{fA} \beta$ induces neuronal loss and a significant increase in iNOS expression by microglia and astrocytes in vivo, suggesting that it is the release of bioactive molecules like nitric oxide by microglia and astrocytes, rather than direct contact between $\mathrm{A} \beta$ fibrils and neurons, that mediates $\mathrm{A} \beta$ neurotoxicity in $\mathrm{AD}$. Note, however, that the expression of NOS by human microglia remains controversial, because evidence supporting induction of reactive nitrogen species in human microglia seems strongly dependent on the experimental methodologies used (Brosnan et al., 1994).

A critical question that must be addressed in examining any animal model of a human disease is how well the animal model mimics the mechanisms and ultimate pathology observed in the human disease. Clearly, there are differences between the present rat model and human AD. First, whereas in the present study gliosis and pathology are observed over a time course of $30 \mathrm{~d}$, in human AD the time course is on the order of decades. Second, the amyloid load per unit of brain area is generally higher and the amyloid distribution more extensive in the human AD brain than in our rat model. However, a key difficulty in addressing the mechanisms of pathology in human AD is that one rarely looks at human brain tissue at the initiation of the disease but rather examines the AD brain at the end stage of the disease, long after the initial mechanisms of pathology occur. A major advantage of the present rat model of $\mathrm{fA} \beta$-induced gliosis and neurotoxicity is that it provides a time- and space-compressed view of the initial changes that $\mathrm{fA} \beta$ induces in the CNS in vivo. Thus, determining how glia serve as intermediaries in the apparent $\mathrm{fA} \beta$-induced neurotoxicity observed in the present model should shed significant light on the mechanisms of fA $\beta$-induced neurotoxicity and allow one to test whether therapeutic interventions can block this effect.

\section{REFERENCES}

Adamson DC, Wildemann B, Sasaki M, Glass JD, McArthur JC, Christov VI, Dawson TM, Dawson VL (1996) Immunologic NO synthaseelevation in severe AIDS dementia and induction by HIV-1 Gp41. Science 274:1917-1921.

Akiyama H, Schwab C, Kondo H, Mori H, Kametani F, Ikeda K, McGeer PL (1996) Granules in glial cells of patients with Alzheimer's disease are immunopositive for C-terminal sequences of beta-amyloid protein. Neurosci Lett 206:169-172.

Ard MD, Cole GM, Wei J, Mehrle AP, Fratkin JD (1996) Scavenging of Alzheimer's amyloid beta-protein by microglia in culture. J Neurosci Res 43:190-202.

Barron KD (1995) The microglial cell. A historical review. J Neurol Sci 134:57-68.

Bennett BD, Bolam JP (1993) Two populations of calbindin D28kimmunoreactive neurones in the striatum of the rat. Brain Res 610:305-310.

Benson JR, Louie PC, Bradshaw RA (1981) Amino acid analysis of peptides. In: The peptides, Vol 4 (Gross E, Mienhofer J, eds), pp 217-260. New York: Academic.

Bo L, Dawson TM, Wesselingh S, Mork S, Choi S, Kong PA, Hanley D, Trapp BD (1994) Induction of nitric oxide synthase in demyelinating regions of multiple sclerosis brains. Ann Neurol 36:778-786.

Boje KM, Arora PK (1992) Microglial-produced nitric oxide and reactive nitrogen oxides mediate neuronal cell death. Brain Res 587:250-256.

Brelje TC, Wessendorf M, Sorenson RL (1993) Multicolor laser scanning confocal immunofluorescence microscopy: practical application and limitations. In: Methods in cell biology, Vol 38 (Matsumoto B, ed), pp 97-181. San Diego: Academic.

Brosnan CF, Battistini L, Raine CS, Dickson DW, Casadevall A, Lee SC (1994) Reactive nitrogen intermediates in human neuropathology: an overview. Dev Neurosci 16:152-161.
Busciglio J, Gabuzda DH, Matsudaira P, Yankner BA (1993) Generation of beta-amyloid in the secretory pathway in neuronal and nonneuronal cells. Proc Natl Acad Sci USA 90:2092-2096.

Bush AI, Pettingell WH, Multhaup G, Paradis M, Vonsattel JP, Gusella JF, Beyreuther K, Masters CL, Tanzi RE (1994) Rapid induction of Alzheimer A beta amyloid formation by zinc. Science 265:1464-1467.

Canning DR, McKeon RJ, DeWitt DA, Perry G, Wujek JR, Frederickson RC, Silver J (1993) Beta-amyloid of Alzheimer's disease induces reactive gliosis that inhibits axonal outgrowth. Exp Neurol 124:289-298.

Citron M, Oltersdorf T, Haass C, McConlogue L, Hung AY, Seubert P, Vigo-Pelfrey C, Lieberburg I, Selkoe DJ (1992) Mutation of the betaamyloid precursor protein in familial Alzheimer's disease increases beta-protein production. Nature 360:672-674.

Cummings BJ, Cotman CW (1995) Image analysis of beta-amyloid load in Alzheimer's disease and relation to dementia severity. Lancet 346:1524-1528.

DeWitt DA, Silver J (1996) Regenerative failure: a potential mechanism for neuritic dystrophy in Alzheimer's disease. Exp Neurol 142:103-110.

Dickson DW, Ksiezak-Reding H, Liu WK, Davies P, Crowe A, Yen SH (1992) Immunocytochemistry of neurofibrillary tangles with antibodies to subregions of tau protein: identification of hidden and cleaved tau epitopes and a new phosphorylation site. Acta Neuropathol (Berl) 84:596-605.

Eddleston M, Mucke L (1993) Molecular profile of reactive astrocytesimplications for their role in neurologic disease. Neuroscience 54:15-36.

El Khoury J, Hickman SE, Thomas CA, Cao L, Silverstein SC, Loike JD (1996) Scavenger receptor-mediated adhesion of microglia to betaamyloid fibrils. Nature 382:716-719.

Esler WP, Stimson ER, Jennings JM, Ghilardi JR, Mantyh PW, Maggio JE (1996) Zinc-induced aggregation of human and rat beta-amyloid peptides in vitro. J Neurochem 66:723-732.

Esler WP, Stimson ER, Ghilardi JR, Felix AM, Lu Y, Vinters HV, Mantyh PW, Maggio JE (1997) A-beta deposition inhibitor screen using synthetic amyloid. Nature Biotech 15:258-263.

Evans KC, Berger EP, Cho CG, Weisgraber KH, Lansbury Jr PT (1995) Apolipoprotein $\mathrm{E}$ is a kinetic but not a thermodynamic inhibitor of amyloid formation: implications for the pathogenesis and treatment of Alzheimer disease. Proc Natl Acad Sci USA 92:763-767.

Ferrer I, Tunon T, Soriano E, del Rio A, Iraizoz I, Fonseca M, Guionnet N (1993) Calbindin D-28k immunoreactivity in the temporal neocortex in patients with Alzheimer's disease. Clin Neuropathol 12:53-58.

Frackowiak J, Wisniewski HM, Wegiel J, Merz GS, Iqbal K, Wang KC (1992) Ultrastructure of the microglia that phagocytose amyloid and the microglia that produce beta-amyloid fibrils. Acta Neuropathol (Berl) 84:225-233.

Fraser PE, Nguyen JT, Chin DT, Kirschner DA (1992) Effects of sulfate ions on Alzheimer beta/A4 peptide assemblies: implications for amyloid fibril-proteoglycan interactions. J Neurochem 59:1531-1540.

Frautschy SA, Cole GM, Baird A (1992) Phagocytosis and deposition of vascular beta-amyloid in rat brains injected with Alzheimer betaamyloid. Am J Pathol 140:1389-1399.

Games D, Adams D, Alessandrini R, Barbour R, Berthelette P, Blackwell C, Carr T, Clemens J, Donaldson T, Gillespie F, Guido T, Hagopian S, Johnson-Wood K, Khan K, Lee M, Leibowitz P, Lieberburg I, Little S, Masliah E, McConlogue L, Montoya-Zavala M, Mucke L, Paganini L, Penniman E, Power M, Schenk D, Seubert P, Snyder B, Soriano F, Tan H, Vitale J, Wadsworth S, Wolozin B, Zhao J (1995) Alzheimer-type neuropathology in transgenic mice overexpressing V717F $\beta$-amyloid precursor protein. Nature 373:523-527.

Giovannelli L, Casamenti F, Scali C, Bartolini L, Pepeu G (1995) Differential effects of amyloid peptides $\beta-(1-40)$ and $\beta-(25-35)$ injections into the rat nucleus basalis. Neuroscience 66:781-792.

Giulian D, Haverkamp LJ, Li J, Karshin WL, Yu J, Tom D, Li X, Kirkpatrick JB (1995) Senile plaques stimulate microglia to release a neurotoxin found in Alzheimer brain. Neurochem Int 27:119-137.

Giulian D, Haverkamp LJ, Yu JH, Karshin W, Tom D, Li J, Kirkpatrick J, Kuo YM, Roher AE (1996) Specific domains of beta-amyloid from Alzheimer plaques elicit neuron killing in human microglia. J Neurosci 16:6021-6037.

Glenner GG, Wong CW (1984) Alzheimer's disease and Down's syndrome: sharing of a unique cerebrovascular amyloid fibril protein. Biochem Biophys Res Commun 122:1131-1135.

Goate A, Chartier-Harlin MC, Mullan M, Brown J, Crawford F, Fidani L, Giuffra L, Haynes A, Irving N, James L, Mant R, Newton P, Rooke K, 
Roques P, Talbot C, Pericak-Vance M, Roses A, Williamson R, Rossor M, Owen M, Hardy J (1991) Segregation of a missense mutation in the amyloid precursor protein gene with familial Alzheimer's disease. Nature 349:704-706.

Goodwin JL, Uemura E, Cunnick JE (1995) Microglial release of nitric oxide by the synergistic action of beta-amyloid and IFN-gamma. Brain Res 692:207-214.

Gramsbergen JB, van den Berg KJ (1994) Regional and temporal profiles of calcium accumulation and glial fibrillary acidic protein levels in rat brain after systemic injection of kainic acid. Brain Res 667:216-228.

Haass C, Schlossmacher MG, Hung AY, Vigo-Pelfrey C, Mellon A, Ostaszewski BL, Lieberburg I, Koo EH, Schenk D, Teplow DB, Selkoe DJ (1992) Amyloid beta-peptide is produced by cultured cells during normal metabolism. Nature 359:322-325.

Haga S, Ikeda K, Sato M, Ishii T (1993) Synthetic Alzheimer amyloid beta/A4 peptides enhance production of complement C3 component by cultured microglial cells. Brain Res 601:88-94.

Harrigan MR, Kunkel DD, Nguyen LB, Malouf AT (1995) Beta amyloid is neurotoxic in hippocampal slice cultures. Neurobiol Aging 16:779-789.

Ishii T, Haga S (1992) Complements, microglial cells and amyloid fibril formation. Res Immunol 143:614-616.

Itagaki S, McGeer PL, Akiyama H, Zhu S, Selkoe D (1989) Relationship of microglia and astrocytes to amyloid deposits of Alzheimer disease. J Neuroimmunol 24:173-182.

Jarrett JT, Lansbury Jr PT (1992) Amyloid fibril formation requires a chemically discriminating nucleation event: studies of an amyloidogenic sequence from the bacterial protein OsmB. Biochemistry 31:12345-12352.

Jarrett JT, Lansbury Jr PT (1993) Seeding "one-dimensional crystallization" of amyloid: a pathogenic mechanism in Alzheimer's disease and scrapie? Cell 73:1055-1058.

Jarrett JT, Berger EP, Lansbury Jr PT (1993) The carboxy terminus of the beta amyloid protein is critical for the seeding of amyloid formation: implications for the pathogenesis of Alzheimer's disease. Biochemistry 32:4693-4697.

Jarrett JT, Costa PR, Griffin RG, Lansbury Jr PT (1994) Models of the beta protein C-terminus: differences in amyloid structure may lead to segregation of "long" and "short" fibrils. J Am Chem Soc 116:9741-9742.

Kang J, Lemaire HG, Unterbeck A, Salbaum JM, Masters CL, Grzeschik KH, Multhaup G, Beyreuther K, Muller-Hill B (1987) The precursor of Alzheimer's disease amyloid A4 protein resembles a cell-surface receptor. Nature 325:733-736.

Kawaguchi Y, Wilson CJ, Augood SJ, Emson PC (1995) Striatal interneurones: chemical, physiological and morphological characterization. Trends Neurosci 18:527-535.

Kelly JF, Furukawa K, Barger SW, Rengen MR, Mark RJ, Blanc EM, Roth GS, Mattson MP (1996) Amyloid beta-peptide disrupts carbachol-induced muscarinic cholinergic signal transduction in cortical neurons. Proc Natl Acad Sci USA 93:6753-6758.

Kennedy WR, Wendelschafer-Crabb G, Brelje TC (1994) Innervation and vasculature of human sweat glands: an immunohistochemistrylaser scanning confocal fluorescence microscopy study. J Neurosci 14:6825-6833.

Kirschner DA, Abraham C, Selkoe DJ (1986) X-ray diffraction from intraneuronal paired helical filaments and extraneuronal amyloid fibers in Alzheimer disease indicates cross-beta conformation. Proc Natl Acad Sci USA 83:503-507.

Kirschner DA, Inouye H, Duffy LK, Sinclair A, Lind M, Selkoe DJ (1987) Synthetic peptide homologous to beta protein from Alzheimer disease forms amyloid-like fibrils in vitro. Proc Natl Acad Sci USA 84:6953-6957.

Klegeris A, Walker DG, McGeer PL (1994) Activation of macrophages by Alzheimer beta amyloid peptide. Biochem Biophys Res Commun 199:984-991.

Koh JY, Yang LL, Cotman CW (1990) Beta-amyloid protein increases the vulnerability of cultured cortical neurons to excitotoxic damage. Brain Res 533:315-320.

Ma J, Yee A, Brewer Jr HB, Das S, Potter H (1994) Amyloid-associated proteins alpha 1-antichymotrypsin and apolipoprotein E promote assembly of Alzheimer beta-protein into filaments. Nature 372:92-94.

Mantyh PW, Ghilardi JR, Rogers S, DeMaster E, Allen CJ, Stimson ER, Maggio JE (1993) Aluminum, iron, and zinc ions promote aggregation of physiological concentrations of beta-amyloid peptide. J Neurochem 61:1171-1174.
Mattson MP, Cheng B, Davis D, Bryant K, Lieberburg I, Rydel RE (1992) Beta-amyloid peptides destabilize calcium homeostasis and render human cortical neurons vulnerable to excitotoxicity. J Neurosci 12:376-389.

McGeer PL, McGeer EG (1996) Anti-inflammatory drugs in the fight against Alzheimer's disease. Ann NY Acad Sci 777:213-220.

Meda L, Cassatella MA, Szendrei GI, Otvos Jr L, Baron P, Villalba M, Ferrari D, Rossi F (1995) Activation of microglial cells by betaamyloid protein and interferon-gamma. Nature 374:647-650.

Mrak RE, Sheng JG, Griffin WS (1995) Glial cytokines in Alzheimer's disease: review and pathogenic implications. Hum Pathol 26:816-823.

Murphy S, Simmons ML, Agullo L, Garcia A, Feinstein DL, Galea E, Reis DJ, Minc-Golomb D, Schwartz JP (1993) Synthesis of nitric oxide in CNS glial cells. Trends Neurosci 16:323-328.

Nishiyama E, Ohwada J, Iwamoto N, Arai H (1993) Selective loss of calbindin D28K-immunoreactive neurons in the cortical layer II in brains of Alzheimer's disease: a morphometric study. Neurosci Lett 163:223-226.

O'Callaghan JP, Jensen KF, Miller DB (1995) Quantitative aspects of drug and toxicant-induced astrogliosis. Neurochem Int 26:115-124.

Paresce DM, Ghosh RN, Maxfield FR (1996) Microglial cells internalize aggregates of the Alzheimer's disease amyloid beta-protein via a scavenger receptor. Neuron 17:553-565.

Paxinos G, Watson C (1986) The rat brain in stereotaxic coordinates. North Ryde, New South Wales, Australia: Academic.

Pike CJ, Walencewicz AJ, Glabe CG, Cotman CW (1991a) Aggregationrelated toxicity of synthetic beta-amyloid protein in hippocampal cultures. Eur J Pharmacol 207:367-368.

Pike CJ, Walencewicz AJ, Glabe CG, Cotman CW (1991b) In vitro aging of beta-amyloid protein causes peptide aggregation and neurotoxicity. Brain Res 563:311-314.

Pike CJ, Burdick D, Walencewicz AJ, Glabe CG, Cotman CW (1993) Neurodegeneration induced by beta-amyloid peptides in vitro: the role of peptide assembly state. J Neurosci 13:1676-1687.

Pike CJ, Cummings BJ, Monzavi R, Cotman CW (1994) Beta-amyloidinduced changes in cultured astrocytes parallel reactive astrocytosis associated with senile plaques in Alzheimer's disease. Neuroscience 63:517-531.

Pike CJ, Walencewicz-Wasserman AJ, Kosmoski J, Cribbs DH, Glabe CG, Cotman CW (1995) Structure-activity analyses of beta-amyloid peptides: contributions of the beta $25-35$ region to aggregation and neurotoxicity. J Neurochem 64:253-265.

Price DL, Borchelt DR, Walker LC, Sisodia SS (1992) Toxicity of synthetic $\mathrm{A} \beta$ peptides and modeling of Alzheimer's disease. Neurobiology of Aging 13:623-625.

Sanan DA, Weisgraber KH, Russell SJ, Mahley RW, Huang D, Saunders A, Schmechel D, Wisniewski T, Frangione B, Roses AD, Strittmatter WJ (1994) Apolipoprotein E associates with beta amyloid peptide of Alzheimer's disease to form novel monofibrils. Isoform apoE4 associates more efficiently than apoE3. J Clin Invest 94:860-869.

Scheuner D, Eckman C, Jensen M, Song X, Citron M, Suzuki N, Bird TD, Hardy J, Hutton M, Kukull W, Larson E, Levy-Lahad E, Viitanen M, Peskind E, Poorkaj P, Schellenberg G, Tanzi R, Wasco W, Lannfelt L, Selkoe D, Younkin S (1996) Secreted amyloid beta-protein similar to that in the senile plaques of Alzheimer's disease is increased in vivo by the presenilin 1 and 2 and APP mutations linked to familial Alzheimer's disease. Nat Med 2:864-870.

Scott SA, Johnson SA, Zarow C, Perlmutter LS (1993) Inability to detect beta-amyloid protein precursor mRNA in Alzheimer plaqueassociated microglia. Exp Neurol 121:113-118.

Selden N, Geula C, Hersh L, Mesulam MM (1994) Human striatum: chemoarchitecture of the caudate nucleus, putamen and ventral striatum in health and Alzheimer's disease. Neuroscience 60:621-636.

Selkoe DJ (1991) The molecular pathology of Alzheimer's disease. Neuron 6:487-498.

Selkoe DJ (1994) Alzheimer's disease: a central role for amyloid. J Neuropathol Exp Neurol 53:438-447.

Selkoe DJ (1997) Alzheimer's disease-genotypes, phenotype, and treatments. Science 275:630-631.

Selkoe DJ, Abraham CR (1986) Isolation of paired helical filaments and amyloid fibers from human brain. Methods Enzymol 134:388-404.

Seubert P, Vigo-Pelfrey C, Esch F, Lee M, Dovey H, Davis D, Sinha S, Schlossmacher M, McCormack R, Wolfert R, Selkoe D, Lieberburg I, Schenk D (1992) Isolation and quantification of soluble Alzheimer's beta-peptide from biological fluids. Nature 359:325-327. 
Shaffer LM, Dority MD, Gupta-Bansal R, Frederickson RC, Younkin SG, Brunden KR (1995) Amyloid beta protein (A beta) removal by neuroglial cells in culture. Neurobiol Aging 16:737-745.

Shoji M, Golde TE, Ghiso J, Cheung TT, Estus S, Shaffer LM, Cai XD, McKay DM, Tintner R, Frangione B, Younkin SG (1992) Production of the Alzheimer amyloid beta protein by normal proteolytic processing. Science 258:126-129.

Soreghan B, Kosmoski J, Glabe C (1994) Surfactant properties of Alzheimer's A beta peptides and the mechanism of amyloid aggregation. J Biol Chem 269:28551-28554.

Uchihara T, Kondo H, Akiyama H, Ikeda K (1995) Single-laser threecolor immunolabeling of a histological section by laser scanning microscopy: application to senile plaque-related structures in post-mortem human brain tissue. J Histochem Cytochem 43:103-106.

van Gool WA, Kuiper MA, Walstra GJ, Wolters EC, Bolhuis PA (1995) Concentrations of amyloid beta protein in cerebrospinal fluid of patients with Alzheimer's disease. Ann Neurol 37:277-279.
Waldvogel HJ, Faull RL, Williams MN, Dragunow M (1991) Differential sensitivity of calbindin and parvalbumin immunoreactive cells in the striatum to excitotoxins. Brain Res 546:329-335.

Wisniewski T, Castano EM, Golabek A, Vogel T, Frangione B (1994) Acceleration of Alzheimer's fibril formation by apolipoprotein E in vitro. Am J Pathol 145:1030-1035.

Wong M-L, Rettori V, Al-Shekhlee A, Bongiorno PB, Canteros G, McCann SM, Gold PW, Licinio J (1996) Inducible nitric oxide synthase gene expression in the brain during systemic inflammation. Nat Med 2:581-584.

Yan SD, Chen X, Fu J, Chen M, Zhu HJ, Roher A, Slattery T, Zhao L, Nagashima M, Morser J, Migheli A, Nawroth P, Stern D, Schmidt AM (1996) RAGE and amyloid-beta peptide neurotoxicity in Alzheimer's disease. Nature 382:685-691.

Yankner BA, Duffy LK, Kirschner DA (1990) Neurotrophic and neurotoxic effects of amyloid beta protein: reversal by tachykinin neuropeptides. Science 250:279-282. 